\title{
The Employment of Working-Age People with Disabilities in the 1980s and 1990s What Current Data Can and Cannot Tell Us
}

\author{
Richard V. Burkhauser \\ Department of Policy Analysis and Management \\ Cornell University \\ Mary C. Daly* \\ Federal Reserve Bank of San Francisco \\ Andrew J. Houtenville \\ School of Industrial and Labor Relations \\ Cornell University \\ Nigar Nargis \\ Department of Economics \\ Cornell University
}

This Draft: November 20, 2001

First Draft: March 1, 2001

We thank J.S. Butler, Dave Stapleton, Dave Wittenburg, and participants at the Cornell Employment and Disability Policy Summer Institute and the 7th National Disability Statistics and Policy Forum: Disability and Participation hosted by the Disability Statistics Center, University of California, San Francisco, for helpful comments. We also thank Carol D'Souza for research support and Anita Todd for editorial assistance. None of these individuals are responsible for any errors. This research is funded in part by the United States Department of Education, National Institute on Disability and Rehabilitation Research, cooperative agreement No. 13313980038. It does not necessarily reflect the view of the National Institute on Disability and Rehabilitation Research or the Federal Reserve Bank of San Francisco.

*Corresponding author: Mary C. Daly, Economic Research Department, Federal Reserve Bank of San Francisco, 101 Market Street, Mail Stop 1130, San Francisco, CA 94105. Ph: (415) 974-3186, Fax: (415) 977-4054, email: mary.daly@sf.frb.org. 


\title{
The Employment of Working-Age People with Disabilities in the 1980s and 1990s What Current Data Can and Cannot Tell Us
}

\begin{abstract}
A new and highly controversial literature argues that the employment of working-age people with disabilities fell dramatically relative to the rest of the working-age population in the 1990s. Some dismiss these results as fundamentally flawed because they come from a selfreported work limitation-based disability population that captures neither the actual population with disabilities nor its employment trends. In this paper, we examine the merits of these criticisms. We first consider some of the difficulties of defining and consistently measuring the population with disabilities. We then discuss how these measurement difficulties potentially bias empirical estimates of the prevalence of disability and of the employment behavior of those with disabilities. Having provided a context for our analysis, we use data from the National Health Interview Survey (NHIS) to compare the prevalence and employment rates across two empirical populations of those with disabilities: one defined by self-reported impairments and one defined by self-reported work limitations. We find that although traditional work limitation-based definitions underestimate the size of the broader population with health impairments, the employment trends in the populations defined by work limitations and impairments are not significantly different from one another over the 1980s and 1990s. We then show that the trends in employment observed for the NHIS population defined by self-reported work limitations are statistically similar to those found in the Current Population Survey (CPS). Based on this analysis, we argue that nationally representative employment-based data sets like the CPS can be used to monitor the employment trends of those with disabilities over the past two decades.
\end{abstract}




\section{The Employment of Working-Age People with Disabilities in the 1980s and 1990s What Current Data Can and Cannot Tell Us}

Using data from the Current Population Survey (CPS), a new and highly controversial literature argues that the employment of working-age people with disabilities fell dramatically relative to the rest of the working-age population in the 1990s. (See especially: Acemoglu and Angrist, forthcoming; Autor and Duggan, 2001; Bound and Waidmann, 2000; Burkhauser, Daly and Houtenville, 2001; DeLeire, 2000.) While many researchers debate the causes for this decline, some dismiss these results altogether, arguing that the work limitation-based disability questions available in the CPS are fundamentally flawed and capture neither the actual population with disabilities (Hale, 2001) nor its employment trends (Kaye, 2001; Kirchner, 1996; Kruse and Schur, 2000; McNeil, 2000). ${ }^{1}$

The basis for these criticisms are long-standing concerns regarding the accuracy and consistency of self-reported measures of health and work limitation (see Bound and Burkhauser, 1999 and Moore, 2001 for reviews of this literature). For one, self-evaluated health is a subjective measure that may not be comparable across respondents or over time (Kirchner, 1996). ${ }^{2}$ Second, these responses may not be independent of the observed variables one wants to

\footnotetext{
${ }^{1}$ As we will discuss later, hypotheses for the decline include unintended consequences of the Americans with Disabilities Act (Acemoglu and Angrist, forthcoming; DeLiere, 2000), increases in disability benefit rolls (Autor and Duggan, 2001, Bound and Waidmann; 2000), and increased severity of health impairments (Kaye, 2001).

${ }^{2}$ Kirchner argues that self-perception within the broader population with disabilities changed with the passage of the Americans with Disabilities Act, making people with impairments less likely to describe themselves as having a work-limiting condition if they were working. Below, we test whether such changes in reporting behavior are reflected in changes in the relationship between the populations with disabilities defined by self-reported impairments and self-reported work limitations. We also test for whether changes in the composition of the population reporting work limitations over time is driving the employment trends found in the CPS.
} 
explain, such as employment status (Chirikos and Nestel 1984; Chirikos 1995). Third, since society may stigmatize those who are able to work but who want to retire before the "normal" retirement age, reasonably healthy individuals who wish to exit the labor force "prematurely" may use poor health as their excuse (Parsons 1980a,b, 1982; Bazzoli, 1985). Finally, since federal disability transfer benefits are available only to those judged unable to perform any substantial gainful activity, individuals with a health problem may have a financial incentive to identify themselves as incapable of work because of their health (Waidmann, et al. 1995). These problems of misclassification can bias estimates of the true number of persons with disabilities and their behavior. More importantly, changes in this mismeasurement over time can bias our estimates of the trends in outcomes (e.g., employment) among those with disabilities.

While the potential for bias inherent in measures of disability has led some researchers (Myers, 1982, 1983; Hale, 2001) to conclude that no useful information can be gained from such data, we argue that this statement is too broad. In this paper, we offer basic empirical tests of these assertions. Using data from the National Health Interview Survey (NHIS) we examine the extent to which self-reported work limitation-based measures misestimate the population of individuals with disabilities. We then investigate whether mismeasurement of the "true" population with disabilities biases estimates of employment, a key outcome variable for those with disabilities. Finally, since the debate over what, if anything, should be done to reverse the downward trend in employment among men and women with disabilities during the 1990s 
currently is focused on the validity of the CPS data, we compare employment outcomes from the NHIS with those from the CPS. ${ }^{3}$

We find that self-reported work limitation-based data underestimate the size of the broad working-age population with serious impairments and disproportionately capture those who are less likely to be employed in the impaired population. We then show that while there are significant differences in the size of the population with disabilities captured by the impairment and work-limitation questions, the employment trends in the broader impaired population from the NHIS and in the work-limited populations in the NHIS and CPS are not significantly different from one another over the 1980s and 1990s. Based on these data, we argue that unlike the 1980s when the employment trends of both those with and without disabilities were procyclical, in the 1990s, working-age people with disabilities experienced substantial declines in their employment rates even during an extended period of economic growth.

\section{Defining and Measuring the Population with Disabilities}

\section{Definitions of Disability}

Evaluation of the working-age population with disabilities must start with a definition of that population. Unfortunately, unlike age, race, or gender, which are relatively straightforward and easily determined demographic characteristics, disability has proven to be a far more

\footnotetext{
${ }^{3}$ The importance of this issue is apparent in a recent research summary by Hale (2001). Hale argues that because the CPS is not designed to measure a specific definition of disability, the burden of proof of its reasonableness is on those who use it. He then writes, "To proceed as though the data are valid measures of disabilities turns a data issue into a policy issue."
} 
controversial concept to define and measure. ${ }^{4}$ Mashaw and Reno (1996) document over twenty definitions of disability used for the purposes of entitlement to public or private income transfers, government services, or statistical analysis, and argue that the appropriateness of any definition of disability depends on the purpose for which it is used.

The variation in disability definitions is apparent across the two main federal policy initiatives to protect those with disabilities. In the Americans with Disabilities Act of 1990 (ADA), disability is defined very broadly as a physical or mental impairment that substantially limits one or more major life activities, a record of such an impairment, or being regarded as having such an impairment. ${ }^{5}$ In contrast, the disability definition used by the Social Security Administration to determine eligibility for both Social Security Disability Insurance (SSDI) and Supplemental Security Income (SSI) benefits is quite narrow. In both SSDI and SSI, benefits are limited to those who are unable to perform "any substantial gainful activity" as the result of a specific set of medical listings (a combination of pathology and functional measures) or a combination of specific medical listings and vocational characteristics that predict future work capacity. Clearly, the ADA definition is meant to ensure that a much larger group of people is

\footnotetext{
${ }^{4}$ While there is little controversy over the objective standards for measuring age, the justification for using age as a standard for ability to work and for "age-based" welfare benefits is more controversial. For instance, a literature exists which argues that categorical age is not a useful measure of ability to work. (See Library of Congress, 1998.) In addition, the Age Discrimination and Employment Act, which provides protection against age discrimination, parallels the Americans with Disabilities Act, which provides protection against discrimination based on disability. But if age is not a useful measure for determining ability to work, then should the Supplemental Security Income program (SSI) guarantee a minimum safety net on income to all those aged 65 and over, but not those younger persons in similar economic circumstances? The controversy surrounding these issues suggests that social concepts of the rights and responsibilities of both older persons and persons with disabilities with respect to work have been undergoing major revisions over the last few decades. (See Daly and Burkhauser, forthcoming, for a fuller discussion of the underlying policy issues related to age or disability status as categorical standards for SSI eligibility.)

${ }^{5}$ LaPlante (1991) provides a useful discussion of alternative definitions that can be used to estimate this population.
} 
guaranteed access to work than is entitled to transfer income benefits by the Social Security Administration definition if they do not work.

Although there is no universal agreement on the most appropriate definition of the population with disabilities, it is possible to place the various definitions used in a common conceptual framework. The most frequently applied model of disability comes from Nagi (1965, 1969, 1991). In the Nagi model, disability is a dynamic process in which an individual's pathology interacts with the socioeconomic environment. ${ }^{6}$ The dynamic nature of the disability process is represented by the movement through three stages: pathology, impairment, and disability. The first stage, pathology, is the presence of a physical or mental condition that interrupts the physical or mental process of the human body. An example is deafness. This leads to the second stage, impairment, which Nagi defines as a physiological, anatomical, or mental loss or abnormality that limits a person's capacity to function. For example, deafness limits the ability to interpret sound. The final stage, disability, is an inability to perform or a limitation in performing roles and tasks that are socially expected. For example, a person with deafness is unable to use the telephone. Under the Nagi model, those with a pathology that causes a physical or mental impairment that subsequently limits one or more life activities—such as work—but who nevertheless work would not be considered to have a work disability. (This is the case whether

${ }^{6}$ The World Health Organization (WHO) has a model of disability very similar to that of Nagi. The key to both of these definitions is the recognition that individuals move from the presence of a health condition to a point where it begins to impinge on activities that are socially expected of them and that this movement is related to the environment in which individuals live. See Jette and Badley (2000) for an excellent comparison of the Nagi and WHO models. 
work was possible though changes in the work environment, access to rehabilitation, or individual adaptability. $)^{7}$

\section{Problems with Measurement}

Most of the new work on the employment of people with disabilities comes from the economics literature where researchers' definitions of disability frequently are functions of already available data rather than original data collection or clinical experience. In most surveys of employment and household income, the data available on health come from a small set of questions that ask respondents to assess whether their health limits the kind or amount of work they can perform. As noted earlier, researchers have been cautious in using such global selfreported health measures for a number of reasons. Most recently, Hale (2001) has argued that self-reported work limitation questions from the CPS and other general employment-focused data sets are so poor that new variables must be added to the CPS if we are to make any statements about the outcomes of those with disabilities. ${ }^{8}$

Still, numerous researchers have shown that self-reported measures of work limitations are highly correlated with other more objective assessments of health and with clinical measures of disability (see Bound and Burkhauser (1999) for a review of this literature). Based on these findings and evidence presented here and elsewhere (Burkhauser and Daly, 1996), we argue that such data are capable of identifying people with serious functional limitations and accurately tracking trends in their employment outcomes.

\footnotetext{
${ }^{7}$ For example, a person with deafness who is accommodated at the workplace with an TTY machine that permits him or her to use the telephone. survey.

${ }^{8}$ Hale provides no empirical evidence for this claim and suggests no alternative measures for the
} 


\section{Tracking the Population with Disabilities Using National Survey Data}

\section{The CPS and NHIS Data}

The CPS annually surveys approximately 50,000 United States households (about 150,000 non-institutionalized civilians) and is the main source of official employment and income statistics in the United States. In 1981 the March Demographic Supplement of the CPS began to ask a question about work limitations: "Does anyone in this household have a health problem or disability which prevents them from working or which limits the kind or amount of work they can do? [If so,] who is that? (Anyone else?)" This type of question is consistent with the Nagi framework of disability developing from a pathology that limits a social activity—work—but may systematically miss people with pathologies and impairments who are nevertheless working and do not consider themselves to be work-limited. (See the Appendix Table 1A for a detailed description of the CPS data and the variables used in our analysis.)

Although the CPS is a cross-sectional survey, it does interview respondents over the course of a year. Specifically, the CPS follows housing units over a four month period and then returns eight months later to follow them for another four months. This allows for matching of housing units and multi-period analysis. A sub-sample of the households administered the March Supplement are asked the work limitation question in two consecutive years (March to March). We use these individuals to construct a "matched" CPS sample and define those with work limitation-based disabilities as those who respond positively to the question in March of two consecutive years. The two-period measure of work limitations-based disability should minimize the risks of temporary illnesses and injuries being reported as long-lasting work limitations, a 
concern raised by critics such as Hale (2001). We use the CPS matched sample to check the robustness of the regular CPS cross-sectional results based on single-period disability.

The major advantage of the CPS is that its design and size allow for state-level estimates and that its work limitation question has been consistently asked since 1981. ${ }^{9}$ The CPS was used by Acemoglu and Angrist, forthcoming, Autor and Duggan, 2001; Bound and Waidmann, 2000, and Burkhauser, Daly and Houtenville, 2001 for this latter reason.

The NHIS is an annual cross-sectional survey of approximately 100,000 noninstitutionalized civilians conducted by the U. S. Centers for Disease Control and Prevention. Useful and comparable data are available from 1983 through 1996; the NHIS was changed substantially in 1997, making time-series comparisons after 1996 questionable. Like the CPS data, the NHIS contains a standard work limitations question: "Does any impairment or health problem now keep [person] from working at a job or business? Is [person] limited in the kind or

\footnotetext{
${ }^{9}$ The U.S. Bureau of Census collects two other data sets that can be used to measure the population with disabilities: Decennial Census Long-Form and The Survey of Income and Program Participation (SIPP). In the 1990 Decennial Census Long-Form, the information on disability also is limited to a single work limitations question: "Does this person have a physical, mental or other health condition that has lasted for 6 or more months and which-Limits the kind or amount of work this person can do at a job? (yes/no) Prevents this person from working at a job? (yes/no)" The 2000 Census Long Form has a much improved series of questions focusing on disability. They are as follows: "16. Does this person have any of the following long-lasting conditions: a. Blindness, deafness, or a severe vision or hearing impairment? (yes/no) b. A condition that substantially limits one or more basic physical activities such as walking, climbing stairs, reaching, lifting, or carrying? (yes/no) 17. Because of a physical, mental, or emotional condition lasting 6 months or more, does this person have any difficulty in doing any of the following activities: a. Learning, remembering, or concentrating? (yes/no) b. Dressing, bathing, or getting around inside the home? (yes/no) c. (Answer if this person is 16 years old or over.) Going outside the home alone to shop or visit a doctor's office? (yes/no) d. (Answer if this person is 16 years old or over.) Working at a job or business? (yes/no)." These data were not released at the time we performed our analysis.

The Census Bureau also conducts the Survey of Income and Program Participation, a longitudinal survey of about approximately 14,000 to 36,700 households. The first easily usable panel began in 1988 . The same people are followed every month over a period of about two and one-half years. New samples begin every year or so thereafter. The SIPP allows for dynamic analysis of employment and program participation. The SIPP also contains information on limitations of daily activities, work limitation (similar to the CPS question), and a limited set of specific pathology and impairment categories. DeLeire (2000) and Kruse and Schur (2000) use these data in their work on this topic. See Burkhauser, Houtenville, and Wittenburg (2001) for a comparison of disability trends in the CPS, NHIS, and SIPP.
} 
amount of work [person] can do because of any impairment?" A person with an affirmative response to either question is considered to have a work limitation. NHIS respondents are asked this question early in the survey.

In addition, the NHIS contains detailed impairment-specific information (e.g., "deaf in both ears," "blind in both eyes," etc.) on a subset of survey respondents. ${ }^{10}$ Individuals in this NHIS sub-sample are asked directly about specific impairments. This allows us to capture a random sample of the population with a given set of impairments including those who, despite their impairment, report that they do not have a work limitation. ${ }^{11}$ (See the Appendix Table 1A for a detailed description of the NHIS data and the variables used in our analysis.)

\section{Conceptual Relationships among Tractable Disability Populations}

Figure 1 illustrates how we conceptualize the interrelationships of the disability populations captured by the questions in the CPS and NHIS data. The square represents the entire working-age population. The largest circle within the square represents the largest subset of working-age people with disabilities captured in our data - those who report having a

\footnotetext{
${ }^{10}$ To gather more detailed responses on specific health pathologies and impairments, the NHIS divides respondents into six randomly selected groups. Each group is assigned one of six supplemental surveys known as Condition Lists. Five of the six Condition Lists focus on pathologies; Condition List \#2 focuses on impairments. We use the one-sixth sub-sample of individuals administered Condition List \#2 for all estimates regarding impairments.

${ }^{11}$ The National Health Interview Survey on Disability 1994-1995 (NHIS-D) represents a major effort by the federal government to capture the population with disabilities. The NHIS-D provides data on a set of pathologies, impairments, and activity limitations. A major advantage of the NHIS-D is that it contains extensive information on perceived barriers to work (e.g., lack of transportation) and work supports (e.g., accommodations). Loprest and Maag (2001) provide useful analysis of the existence of barrier to work and work support in broadly defined populations with disabilities. However, small sample sizes within impairment sub-groups limit the specificity of the pathology/impairment categories, and unlike the NHIS, a large number of years cannot be pooled together to boost sample sizes. See Kirchner, Schmeidler and Todorov (1999) for an excellent example of a pathology/impairment specific employment study using the NHIS-D. They perform a detailed analysis of the health and employment experience of those reporting serious visual impairments. See the web site of the Center for Disease Control and Prevention for more information on the NHIS-D.
} 
pathology/impairment. Each wedge represents people with a specific impairment. The NHIS pathology/impairment data best captures this population. ${ }^{12}$ This population is most closely representative of the ADA-eligible population, in that it includes both those who are working despite their impairments and may not report a work limitation as well as those whose impairments and social environment lead them to report a work limitation. ${ }^{13}$

The second largest circle represents people with impairments who report a work limitation, also divided into impairment-specific wedges. This is the group captured by the general work limitation questions in the CPS and NHIS data and the one most closely related to the Nagi conceptualization of work disability. ${ }^{14}$ The smallest circle represents those whose work limitation is so severe that they apply for SSI or SSDI. This is only a small proportion of the larger population with disabilities. (See Burkhauser, Daly, and Houtenville, 2001 for estimates of the size and characteristics of the smaller two circles using CPS data.)

\section{Empirical Relationships among Tractable Disability Populations}

Differences in Levels Across Measures. To begin to assess whether the population with disabilities defined by the self-reported work limitation question is a reasonable proxy for the population with significant impairments, we focus on the relationship between the outermost and middle circles in Figure 1. We first examine the extent to which individuals with a specific

\footnotetext{
${ }^{12}$ Although not represented in Figure 1, these wedges may overlap because individuals can have more than one impairment. The NHIS does not ask a global question on impairment, so we are not able to capture the entire population with impairments. We are able to capture a subset of the impairment wedges pictured in Figure 1.

${ }^{13}$ There is no global question in the NHIS, SIPP, or CPS that attempts to capture all those who have impairments or more broadly who would be considered to have a "disability" under the ADA.

${ }^{14}$ It also is the group captured by other nationally representative data sets focused on employment and economic well-being (e.g., SIPP, Panel Study of Income Dynamics, and the National Longitudinal Survey.)
} 
pathology/impairment report a work limitation. We then investigate the employment behavior of those with a pathology/impairment who do and do not report a work limitation. Since the CPS does not contain data on impairments, our comparisons are based solely on data from the NHIS. As mentioned earlier, in the NHIS survey a subset of respondents are asked about specific health impairments and then about whether they have a work limitation. We use a pooled sample of these individuals (1983-1996) to conduct the analysis reported in Tables 1 and $2 .{ }^{15}$ (See Houtenville 2001 for a detailed description of the NHIS data used in our analysis.)

Table 1 shows the prevalence of self-reported work limitations among working-age men and women with various impairments. The first cell in column one indicates the percentage of men and women who report having any of the impairments in the list. The remaining cells in column one show the percentage of men and women who say they have that specific impairment. Columns two and three show the percentage of those with the listed impairment(s) who report having (column 2) or not having (column 3) a work limitation.

In general, Table 1 supports the notion that the population within the outermost circle of Figure 1 is substantially understated if we use the work limitation question in the NHIS to describe it. While the severity of the impairment undoubtedly explains much of the variance in work limitations in columns 2 and 3, it does not explain all of it. For example, among those who report being deaf in both ears or blind in both eyes_-impairments many would expect to be work limiting_-only 38 (69) percent, respectively, also report being "unable to work or to be limited in the kind or amount of work they do." This suggests that the self-report of a work limitation may

\footnotetext{
${ }^{15}$ The NHIS comparisons are based on a representative one-sixth sub-sample of respondents for the years 1983-1996. Because the prevalence of specific impairments is very low in any given year, we must pool the NHIS data over a number of years to establish a sample size sufficient for analysis.
} 
be influenced by the work environment, rehabilitation opportunities, or the inner capacity of individuals to overcome both their impairments and the barriers to work.

Although Table 1 clearly shows that using a work limitation-based measure of disability will underestimate the size of the population with significant impairments, it is not clear whether this underestimate biases measures of employment for those with disabilities. To investigate this, we examine the employment rates of those with impairments. Table 2, column one reports the employment rates of men and women who say they have one of the impairments on the list. Columns two and three show the employment rates of those with an impairment who report having (column 2) or not having a work limitation (column 3). As illustrated in the first row, controlling for having an impairment, those who say they are not work limited are much more likely to be employed (employment rate of $83.4 \%$ ) than those who say they are work limited (employment rate of $41.5 \%$ ). Returning to the specific examples of those deaf in both ears and blind in both eyes, those who report these impairments but report no work limitation are 2.08 (3.98) times more likely (ratio of column 2 to column 3), respectively, to be employed than such persons who do report a work limitation. This suggests that responses to the standard work limitation questions, available in most nationally representative data sets, are greatly affected by the employment experiences of respondents. Specifically, the data from the NHIS indicate that using a work limitation question to define the population with disabilities systematically excludes individuals with significant impairments who are sufficiently integrated into the workforce that they do not report a work limitation.

Differences in Trends across Measures. Having established that there are significant and systematic differences in population and employment levels of those self-reporting impairments 
and work limitations we now turn to an examination of the trends in these variables. Figure 2 compares the trends in the prevalence of impairments and the prevalence of work limitations in the NHIS between 1983 and 1996 for both men and women. (See Appendix Table 2A for the complete set of prevalence rates underlying Figure 2). Note that in this analysis we focus on two separately identified populations. The first is the population of working-age men and women who report having any of the impairments listed in Table 1. The second is the group of working-age individuals self-reporting a work limitation; these individuals may or may not report a specific impairment. $^{16}$

Figure 2 shows that although the trends in impairment- and work limitation-based disability prevalence in the NHIS exhibit some of the same movements, they do not always follow each other. For example, in the 1990s the prevalence of impairments was falling while the prevalence of work limitations remained relatively stable. To test whether these differences are significant we regress disability prevalence rates (pooled sample across measures) on a dummy variable, indicating whether the prevalence estimate comes from the impairment or work limitations question, a higher-order polynomial time-trend, and the interactions of the time trend and the indicator variables. We then test the joint significance of the interaction terms using an Ftest (see Burkhauser, Houtenville, and Nargis (2001) for a more complete description of our test methodology). Based on this method, we find no significant differences between the time-trends in disability prevalence for men. However, we fail to accept the hypothesis that the trends for

\footnotetext{
${ }^{16}$ The sample universe for the impairment trends is those individuals administered Condition List \#2 in the NHIS. The sample universe for the work limitations trends is the full NHIS sample. 
women are the same across the two measures. (See Appendix Table 3A for the results of these tests.)

What should we make of these findings? First, based on our statistical analysis, we cannot say the trends in prevalence of impairments and work limitations for men are different, suggesting that while the work limitation questions cannot capture the level of impairment-based disability, it does track the trend over time. The same cannot be said for women. However, as Figure 2 shows, the divergence in the two measures goes in a direction opposite the one critics of worklimitations measures worry about (for example, Kirchner, 1996). Namely, during the 1990s, the prevalence of work limitation-based disability moved closer to the prevalence of impairmentbased disability, suggesting that the work limitation-based measures may be capturing a greater, rather than a smaller, share of the population with significant impairments. ${ }^{17}$

As a final test for trend differences in our two NHIS disability populations, Figure 3 compares the employment rates of those self-reporting impairments with those reporting a work limitation over the period 1983-1996. (See Appendix Table 4A for a complete set of the employment rates underlying Figure 3.) Again, the employment patterns across the two measures mirror each other, although with notable divergences from year-to-year. Most importantly for the current debate, the decline in employment among men and women during the 1990s is observed in both the impaired and the work-limited disability populations. Testing for differences in employment trends between the two populations we find no significant differences in their estimated trends (see Appendix Table 3A for the results of these tests).

\footnotetext{
${ }^{17}$ Ideally, we would like to directly test this hypothesis using the detailed NHIS data in Tables 1 and 2. However, small sample sizes prohibit such detailed analysis over time. See Houtenville, 2001 for a complete description of the sample sizes in the NHIS impairment survey. 
Differences in Trends across Data Sets. In this section we move away from comparisons of prevalence and employment of those with disabilities across measures and consider trends in these variables across data sets. Figure 4 compares trends in the work limitation-based disability prevalence among working-age men and women in the CPS, the matched CPS sample, and the NHIS. ${ }^{18}$ (See Appendix Table 5A for the complete set of prevalence rates underlying Figure 4.) As the figure shows, the NHIS work limitation-based prevalence estimates are higher than those from the CPS and the CPS-matched sample for men and women in every year. ${ }^{19}$ The average annual prevalence of work limitation-based disability (1983-1996) among men was 8.1 percent in the CPS-based estimates and 10.3 percent in the NHIS. The average annual prevalence of disability among women over the same period was 7.4 percent in the CPS and 10.4 percent in the NHIS. The prevalence rates for the CPS-matched sample were smaller than for the CPS. These differences are statistically significant in most years of our study. ${ }^{20}$

Again, we also are interested in the extent to which the trends in prevalence observed in the CPS are similar to those observed in the NHIS. Using the same test procedure applied earlier, we find significant differences between the trends in the work limitations-based prevalence of disability in the NHIS and the two CPS samples. Of the four comparisons, the trends are only the

\footnotetext{
${ }^{18}$ The NHIS sample universe is all respondents.
}

${ }^{19}$ One potential explanation for the level of differences in self-reported work limitations in the NHIS and CPS is the location of the work-limitation question in the two surveys. In the CPS, the worklimitation question is asked in a section of the survey focusing on employment; in the NHIS it is asked as part of the basic health and demographic "core" questionnaire. To the extent that individuals already focused on questions about their health would be more apt to disclose a work-limitation , the NHIS would pick up a higher rate of reported disability. Likewise, to the extent that individuals who are not in the labor force for other reasons do not consider themselves work-limited, the question placement in the NHIS may elicit a greater response.

${ }^{20}$ The statistical tests performed were t-tests of the differences in two proportions. 
same for men in the NHIS and CPS-matched sample. (See Appendix Table 6A for the results of these tests.)

Although the prevalence trends clearly are different across the two data sets, we primarily are interested in whether the CPS can be used to follow employment trends for those with disabilities. Figure 5 shows employment rates for men and women with work limitation-based disabilities in the NHIS, CPS, and CPS-matched sample. (See Appendix Table 7A for the complete set of employment rates underlying Figure 5.) As the figure shows, there is a much closer relationship between employment rates for those with disabilities than was true for the prevalence rates. Our statistical tests confirm this. We find no significant differences in the employment trends (1983-1996) for the work limitations-based populations of men and women with disabilities in the NHIS and two CPS samples (see Appendix Table 6A for the results of these tests).

Thus, despite significant differences in the level of self-reported work limitations between the two data sets, the trends in employment found in the two CPS work limitation-based disability populations are not significantly different from those found in the NHIS work limitation-based disability population.

\section{What Do Current Data Tell Us?}

Trends in Employment among Those with Disabilities in the 1980s and 1990s

We now focus on the major issue in the new literature on the employment of people with disabilities. Table 3 shows the sensitivity of employment rates to economic fluctuations over the 
past twenty years for working-age men and women with and without disabilities. ${ }^{21,22}$ As the table shows, during the 1980s the employment of men with and without disabilities was procyclical, falling with recession and rising with recovery. In 1980, the first year the economy began to slow, employment rates of men with and without disabilities were relatively high-42.6 percent and 96.7 percent, respectively. Employment for men with and without disabilities declined as the economy moved through a recession, declining by about 2 percent for each group. Economic recovery once again boosted employment rates among men, particularly those with disabilities. Between 1982 and 1989, the employment rate among men with disabilities rose 5.1 percent, surpassing the 1980 peak. Tests for differences in the levels and trends in employment between men with and without disabilities during the 1980s show a significant difference in the level of employment between men with and without disabilities, but no significant difference in the trends. (See Appendix Table 8A for the results of these tests.)

In the 1990s, the employment experiences of men with and without disabilities began to diverge. For men without disabilities, the familiar procyclical pattern continued; employment fell as the economy moved into recession in the early 1990s but rebounded over the next seven years of economic growth (1992 to 1999). By 1999, the last year of available CPS data, the employment of men without disabilities was near its 1989 peak level. In contrast, the employment

\footnotetext{
Table 7A.

${ }^{21}$ Employment rates (and standard errors) for each year of our sample are reported in Appendix

${ }^{22}$ To trace economic outcomes of people with disabilities over the business cycle we focus on three years representing peak or near peak points-1980, 1989, and 1999 - and two years representing trough points-1982 and 1991. An ideal analysis would make peak to peak comparisons $(1979,1989$, and the next business cycle peak). However, data constraints limit the choice of years compared to 1980 (the first year of data with disability information), 1989 (the peak of the 1980s business cycle), and 1999 (the latest year of data available).
} 
pattern of men with disabilities was quite different over the 1990s. Employment rates among men with disabilities fell as the economy moved into recession, but then continued to fall during the expansion, when job growth was substantial and the employment of men without disabilities was rising. By 1999 the employment rate of working-age men with disabilities had not only failed to return to its 1989 level but was substantially below its 1992 trough year level. Overall, between 1989 and 1999, the employment rate of men with disabilities fell from 44.0 to 34.0 percent, a decline of more than 25 percent. Tests for differences in the trends in employment during the 1990s show a significant difference in the employment trends between men with and without disabilities, unlike during the 1980s. (See Appendix Table 8A for the results of these tests.)

The story for women is similar. The employment of women with and without disabilities was constant in the early recession years of the 1980s business cycle and then increased substantially through the growth years that followed. However, as was the case for men, over the 1990s business cycle the employment experience of women with and without disabilities began to diverge. For women without disabilities, employment remained near its 1989 peak through the recession years of the early 1990s and grew thereafter. In contrast, the employment rate of women with disabilities fell as the economy moved into recession and continued to fall even over the recovery period. Statistical tests confirm that while there is a significant difference in the level of employment rates over the entire period, there is no significant difference in the employment trends for women with and without disabilities in the 1980s. In contrast, and as for the sample of men, there is a significant difference in employment trends in the 1990s. (See Appendix Table 8A for the results of these tests.) 
Finally, to test for the possibility that changes in the composition of the population reporting a work disability are driving the results, we perform a simple shift-share analysis, controlling first for changes in age, race, education, and household size, and then controlling for these demographic changes and changes in employment rates. The results of these analyses, reported in Appendix Table 9A show that if the composition of the population with disabilities was the same in 1999 as it was in 1980 or 1989 (in terms of age, race, education, and household size), the economic outcomes for those with disabilities would be worse than the ones actually found in the data. This suggests that our results are not an artifact of demographic shifts, but rather the result of changing outcomes for those with disabilities.

\section{Discussion and Issues for Future Research}

In Figure 1 we provided a conceptualization of a population with disabilities that operationally placed those who report a Nagi "work limitation-based disability" within a broader ADA-based disability population that recognizes that a reported impairment may or may not lead to a work limitation. Using data from the NHIS we showed that a substantial share of workingage people who report serious impairment do not report having a work limitation. We further showed that those with impairments who also report having a work limitation are far less likely to be employed than are people with the same reported impairment who do not report having a work limitation. This suggests that work limitation questions like those in the CPS are likely to understate the prevalence of disability in the working-age population based on an ADA conceptualization and to understate the share of that population that is employed.

However, we also find that the employment trends in these two distinct conceptualizations of the working-age population with disabilities are not significantly different from one another. 
Using NHIS data we find that the employment trends of this work limitation-based disability population are not significantly different from the employment trends of the larger impairmentbased population. Moreover, we find that while disability prevalence and employment rates found in the CPS data for this work limitation-based disability population are significantly different from those found in the NHIS data, there is no significant difference between the trends in employment found in these data sources.

With this in mind and using the work limitation-based measure of disability in the CPS, we find that during the 1980s and the 1990s, employment outcomes for those without disabilities were procyclical, falling during recessionary years and rising during years of expansion. While this also was the case for working-age men and women with disabilities during the 1980s, it failed to hold for working-age men and women with disabilities in the 1990s. During the 1990s, employment of men and women with disabilities fell continuously, declining in both recessionary and expansionary periods. These results suggest that recent studies using the work limitationbased disability population in the CPS to examine the decline in the relative employment of men with disabilities in the 1990s cannot be dismissed out of hand.

So far, three major hypotheses have been proposed to explain this decline. Kaye (2001) argues that declining employment rates among those with disabilities in the 1990s were caused by dramatic increases in the severity of impairments. Hence, for Kaye, the recent trends are healthbased and not a reflection of changes in public policy. Other researchers have taken a more social environment-oriented view. For example, DeLeire (2000) and Acemoglu and Angrist (forthcoming) attribute the downturn in employment among those with disabilities in the 1990s to the passage of the ADA. Bound and Waidmann (2000) argue that changes in disability benefits 
eligibility and generosity made it easier and more profitable for workers to leave the labor force and take benefits. Autor and Duggan (2001) suggest that a combination of disability benefits that replaced a greater share of labor earnings and declining job opportunities for low-skilled workers induced an increasing share of workers to choose benefits over employment.

So far, however, no studies have been able to satisfactorily disentangle the impact of demand side factors related to the passage of the ADA or changes in the mix of jobs in the economy in the 1990s from supply side factors related to changes in the ease of access to SSDI and SSI benefits or to a reduction in the share of jobs that provide private health insurance, which would discourage work among the population with disabilities. And no one has developed clear empirical evidence that the severity of health impairments has increased over time.

This paper moves the policy debate beyond the question of "Did the employment of people with disabilities dramatically fall in the 1990s?" It did. Pinning down the magnitudes of these various effects is the next necessary step to fully understanding the causes for this decline and developing policies targeted at reversing this trend. 


\section{References}

Acemoglu, Daron and Joshua Angrist. Forthcoming. "Consequences of Employment Protection? The Case of the Americans with Disabilities Act." Journal of Political Economy.

Autor, D. and M. Duggan. 2001. "The Rise in Disability and the Decline in Unemployment." Mimeo, Department of Economics. Cambridge, MA: Massachusetts Institute of Technology.

Bazzoli, Gloria J. 1985. "Evidence on the Influence of Health," Journal of Human Resources, 20(2): 214-234.

Bound, John. 1991. "Self-Reported Versus Objective Measures of Health in Retirement Models," Journal of Human Resources, 26(1)(Winter): 106-138.

Bound, John and Richard V. Burkhauser. 1999. "Economic Analysis of Transfer Programs Targeted on People with Disabilities." In Handbook of Labor Economics, Vol. 3. Edited by Orley Ashenfelter and David Card. New York, Amsterdam?: Elsevier Science, pp. 3417-3528.

Bound, John and Timothy Waidmann. 2000. “Accounting for Recent Declines in Employment Rates among the Working-Aged Disabled.” NBER Working Paper No. W7975. Cambridge, MA: National Bureau of Economic Research.

Burkhauser, Richard V. and Mary C. Daly. 1996. "Employment and Economic Well-Being Following the Onset of a Disability: The Role for Public Policy." In Disability, Work, and Cash Benefits, Jerry Mashaw, Virginia Reno, Richard V. Burkhauser, and Monroe Berkowitz, eds. Kalamazoo, MI: W.E. Upjohn Institute for Employment Research, pp. 59-102.

Burkhauser, Richard V., Mary C. Daly, and Andrew Houtenville. 2001. "How Working-Age People with Disabilities Fared over the 1990s Business Cycle." In Ensuring Health and Income Security for an Aging Workforce. Edited by P. Budetti, R.V. Burkhauser, J. Gregory, and A. Hunt. Kalamazoo, MI: W.E. Upjohn Institute for Employment Research, pp. 291-346.

Burkhauser, Richard V., Andrew Houtenville, and Niger Nargis. 2001. "Comparisons of Time Trends from Two Data Sources.” Economics of Disability Research Report No. 4. Ithaca, NY: Cornell University, Rehabilitation Research Center.

Burkhauser, Richard V., Andrew Houtenville, and David Wittenburg. 2001. "A User Guide to Current Statistics on the Employment of People with Disabilities." Paper presented at the Conference on The Persistence of Low Employment Rates of People with Disabilities-Causes and Policy Implications, October 18-19, 2001, Washington DC. 
Chirikos, Thomas N. 1995. "The Economics of Employment (Title I of the Americans with Disabilities Act)." In Jane West (ed.), The Americans with Disabilities Act: From Policy to Practice. New York: Milbank Memorial Fund.

Chirikos, Thomas N. and Gilbert Nestel. 1984. "Economic Determinants and Consequences of Self-Reported Work Disability," Journal of Health Economics, 3(2): 117-136.

Daly, Mary C., and Richard V. Burkhauser. Forthcoming. "The Supplemental Security Income Program." In Means-Tested Transfer Programs in the United States." Edited by Robert Moffitt. Chicago, Illinois: University of Chicago Press.

DeLeire, Thomas. 2000. "The Wage and Employment Effects of the Americans with Disabilities Act." Journal of Human Resources 35(4): 693-715.

Hale, Thomas. 2001. "The Lack of a Disability Measure in Today's Current Population Survey." Monthly Labor Review. June: pp. 38-40.

Houtenville, Andrew J. 2001. "The Economic Experience of Working Persons with Chronic Vision-Related Impairments." Report prepared for the National Research Council, Commission on Behavioral and Social Science Education.

Jette, Alan and Elizabeth Badley. 2000. "Conceptual Issues in the Measurement of Work Disability." in Survey Measurement of Work Disability, edited by Nancy Mathiowetz and Gooloo Wunderlich. Washington DC: National Academy Press.

Kaye, Steven. 2001 "Improved Employment Opportunities for People with Disabilities." Mimeo, Disability Statistics Center, University of California, San Francisco.

Kirchner, Corinne. 1996. "Looking Under the Street Lamp: Inappropriate Uses of Measures Just Because They are There.” Journal of Disability Policy Studies 7(1): 77-90.

Kirchner, Corrinne, Emilie Schmeidler, and Alexander Todorov. 1999. "Looking at Employment Through a Lifespan Telescope: Age, Health, and Employment Status of People with Serious Visual Impairments." New York, NY: American Foundation for the Blind.

Kruse, Douglas and Lisa Schur. 2000. "Employment of People with Disabilities Following the ADA." Mimeo, School of Management and Labor Relations. New Brunswick, NJ: Rutgers University.

LaPlante, Mitchell P. 1991. “The Demographics of Disability.” In Jane West (ed.), The Americans with Disabilities Act: From Policy to Practice. New York: Milbank Memorial Fund.

Library of Congress. 1998. "Vocational Factors in the Social Security Disability Decision Process: A Review of the Literature. Report prepared under an Interagency Agreement 
for the Social Security Administration Office of Disability Research. The Federal Research Division Library of Congress.

Loprest, Pamela and Elaine Maag. 2001. "Barriers to and Supports for Work among Adults with Disabilities: Results from the NHIS-D." Washington, DC: Urban Institute.

Mashaw, Jerry and Virginia Reno. 1996. Balancing Security and Opportunity: the Challenge of Disability Income Policy. Report of the Disability Policy Panel, National Academy of Social Insurance, Washington, DC.

McNeil, John. 2000. "Employment, Earnings, and Disability." Presented at the $75^{\text {th }}$ Annual Conference of the Western Economic Association. Available at http://www.census.gov/hhes/www/disable/emperndis.pdf.

Moore, Kathryn. 2001. "Raising the Social Security Retirement Ages: Weighing the Costs and Benefits." Arizona State Law Journal, 33(2): 544-612.

Myers, Robert. 1982. "Why Do People Retire from Work Early?” Aging and Work 5:83-91.

Myers, Robert. 1983. "Further Controversies on Early Retirement Study." Aging and Work 6: 105-109.

Nagi, Saad. 1965. "Some Conceptual Issues in Disability and Rehabilitation." In Sociology and Rehabilitation, M.B. Sussman, ed. Washington, DC: American Sociological Association.

Nagi, Saad. 1969. Disability and Rehabilitation: Legal, Clinical and Self-Concepts of Measurement. Columbus: Ohio State University Press.

Nagi, Saad. 1991. "Disability Concepts Revisited: Implications to Prevention." In Disability in America: Toward A National Agenda for Prevention. Edited by A.M. Pope and A.R. Tarlove. Washington, DC: National Academy Press.

Parsons, Donald O. 1980a. "The Decline of Male Labor Force Participation," Journal of Political Economy, February, 88, pp. 117-34.

Parsons, Donald O. 1980b. "Racial Trends in Male Labor Force Participation," American Economic Review, December, 70, pp. 911-20.

Parsons, Donald O. 1982. "The Male Labor Force Participation Decision: Health, Reported Health, and Economic Incentives,” Economica, February, 49, pp. 81-91.

Parsons, Donald O. 1984. "Disability Insurance and Male Labor Force Participation: A Response," Journal of Political Economy, 92(3)(June): 542-549.

Waidmann, Timothy et al. 1995. "The Illusion of Failure: Trends in Self-Reported Health of the U.S. Elderly." Milbank Quarterly 253. 
Figure 1. Conceptual Context of CPS and NHIS Measures of Disability

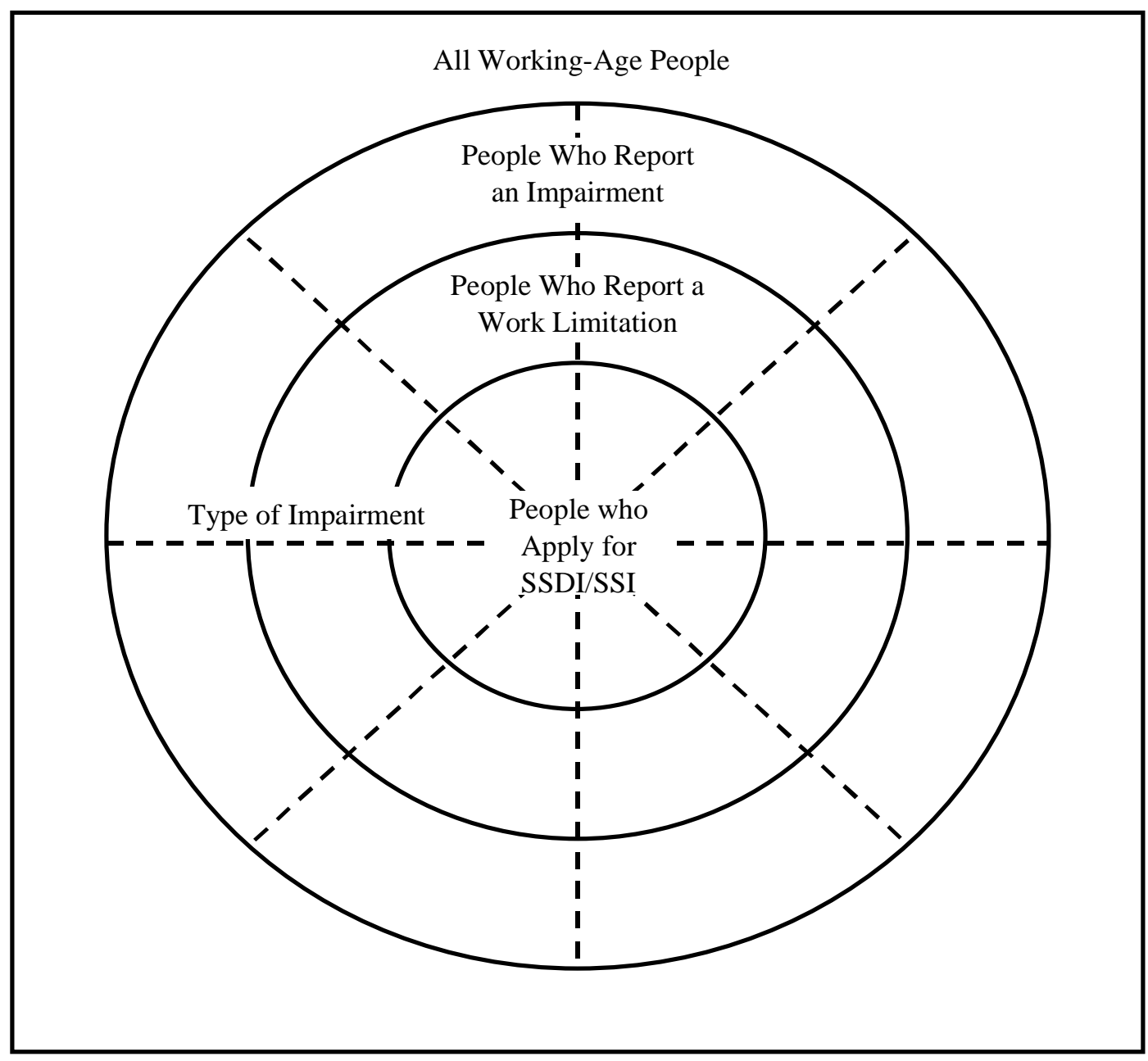


Figure 2. Impairment- and Work Limitation-Based Disability Prevalence in the NHIS by Gender
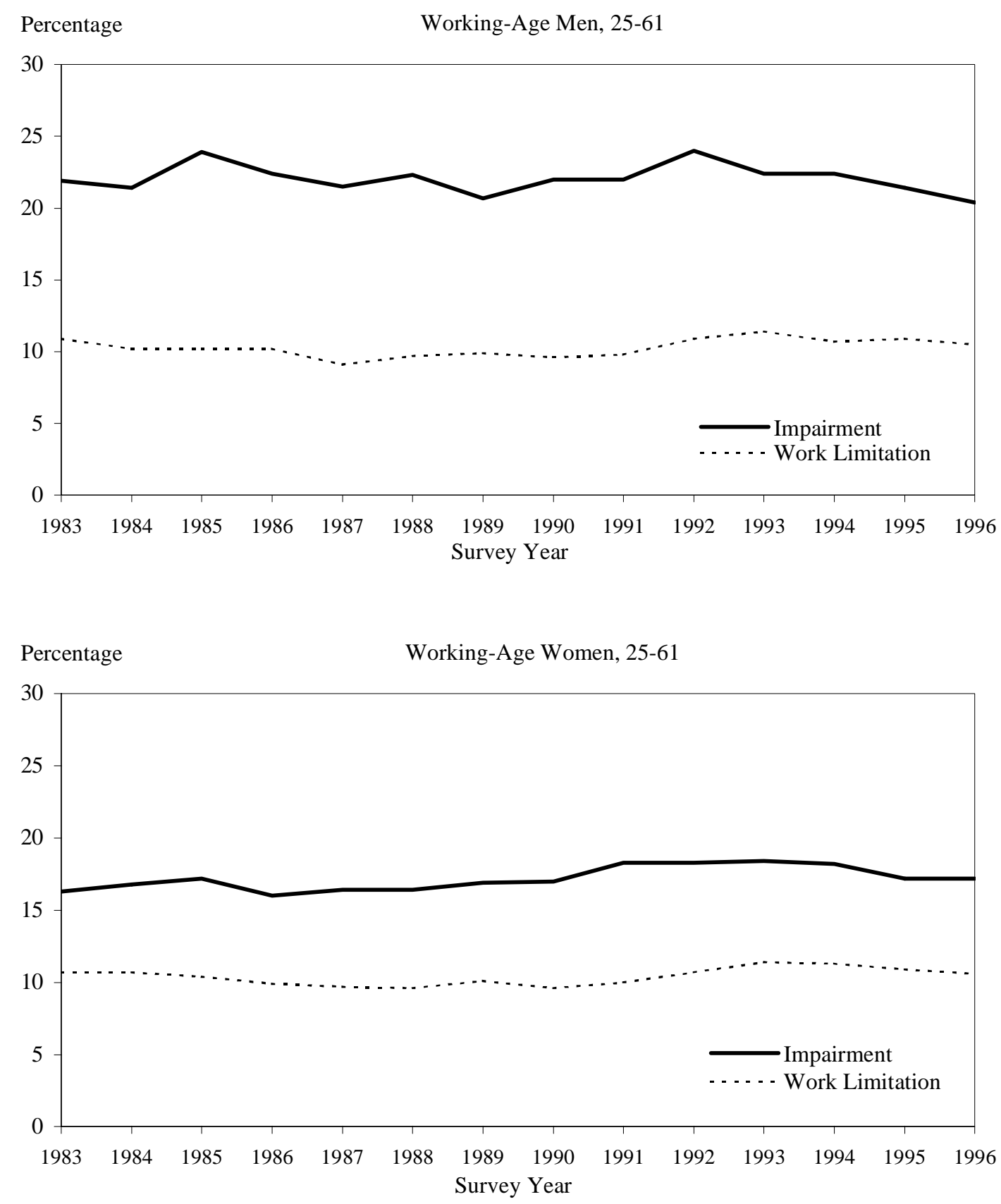

Source: Authors' calculations using the NHIS, 1983-1996. 
Figure 3. Employment Trends Among Working-Age Individuals with Disabilities in the NHIS

by Gender and Disability Definition

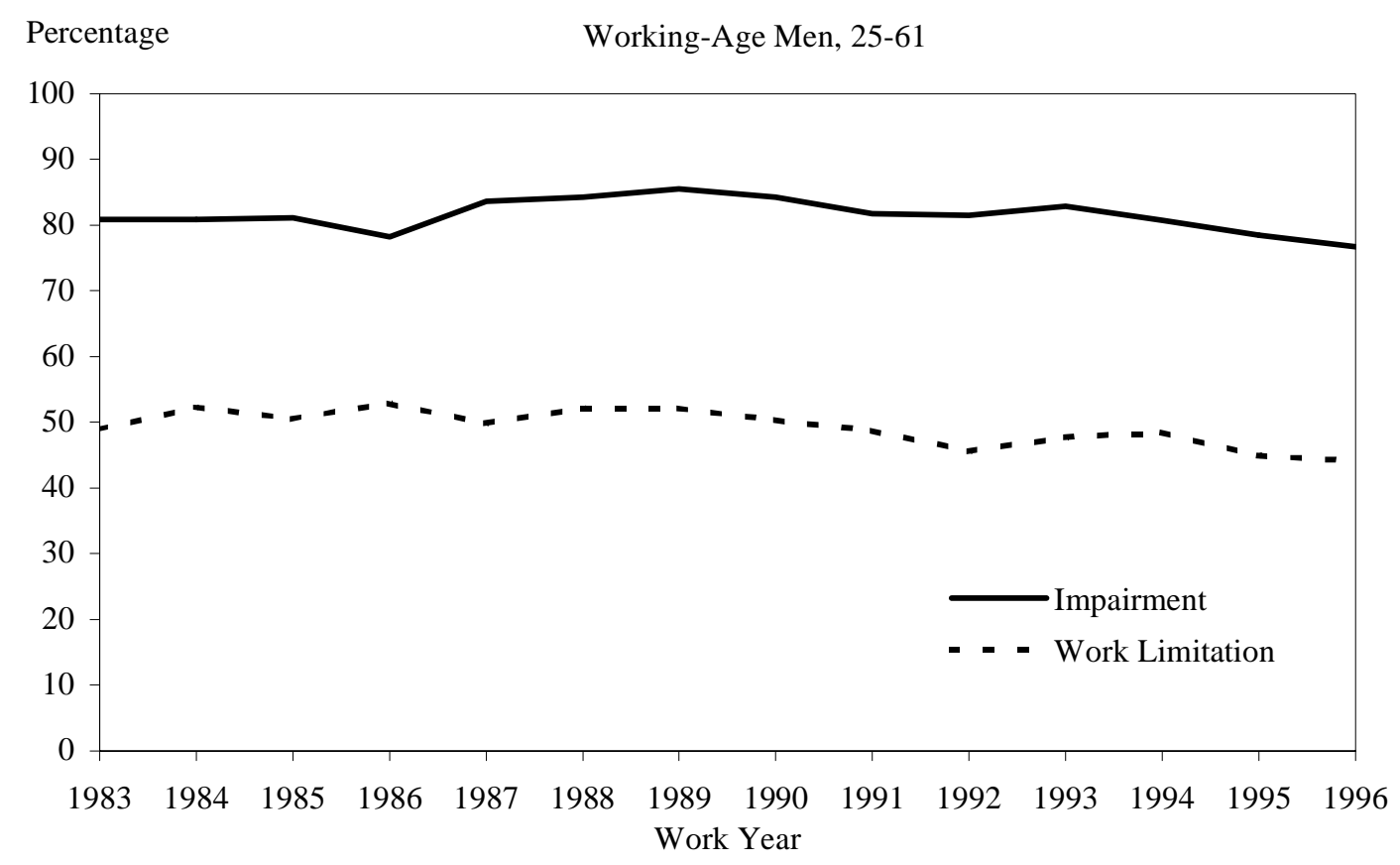

Percentage

Working-Age Women, 25-61

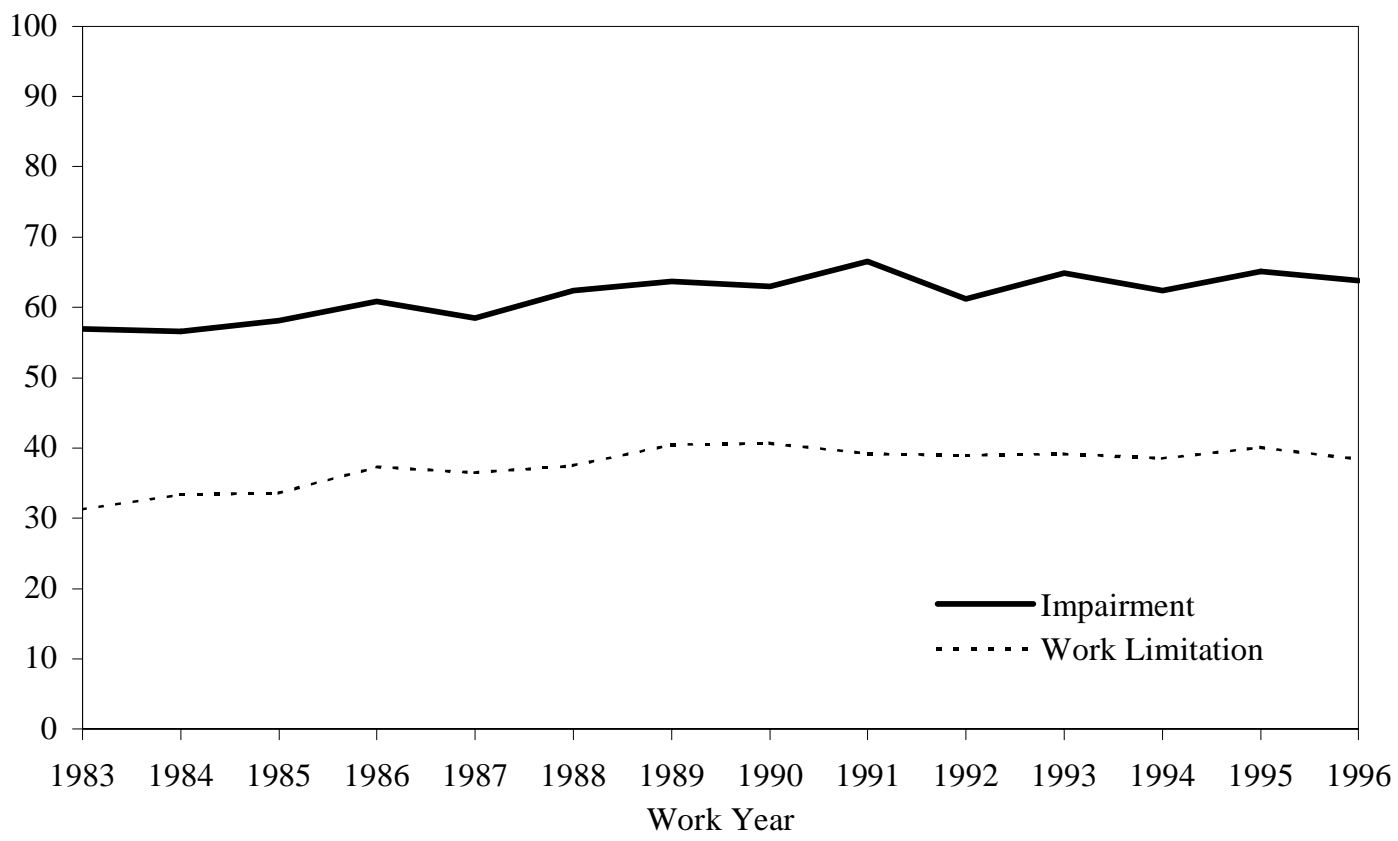

Source: Authors' calculations using the NHIS, 1983-1996. 
Figure 4. Work Limitation-Based Disability Prevalence in the NHIS, CPS, and Matched CPS

by Gender

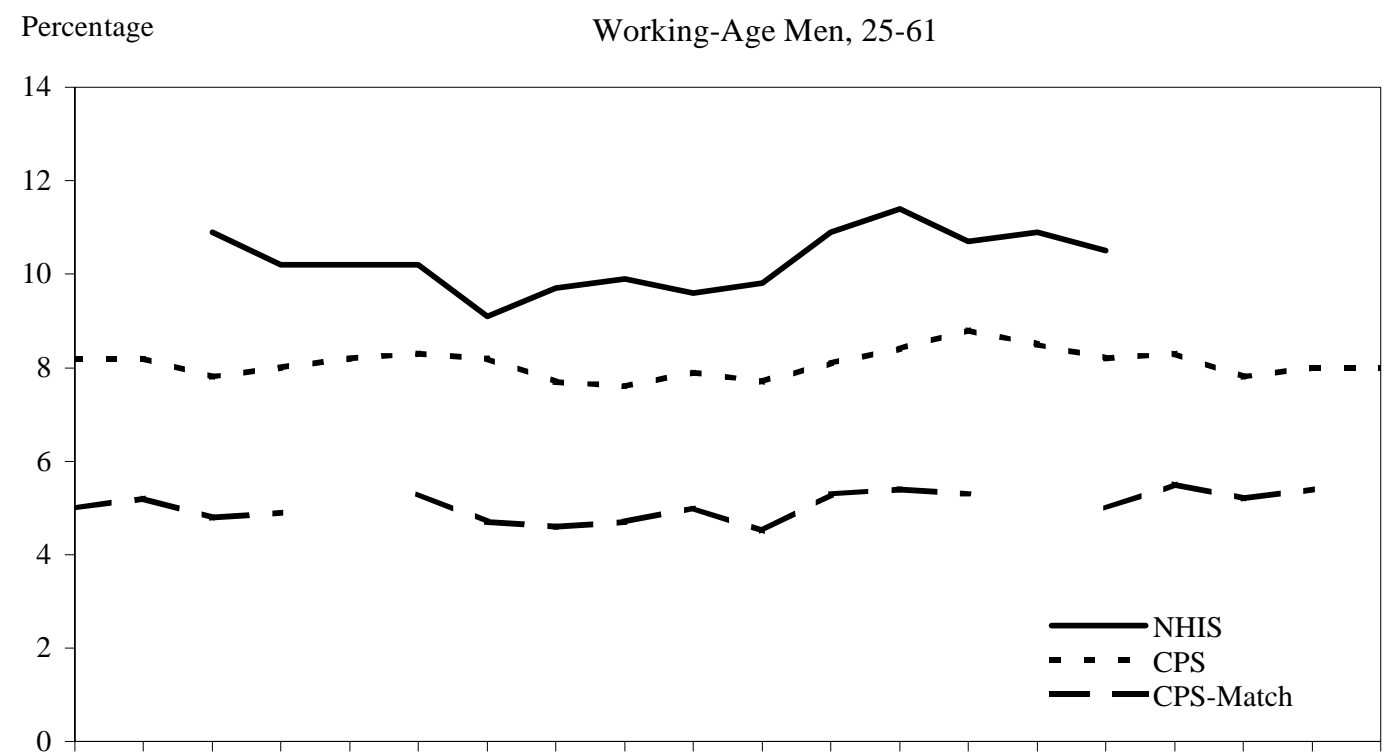

19811982198319841985198619871988198919901991199219931994199519961997199819992000

(First) Survey Year

Percentage $\quad$ Working-Age Women, 25-61

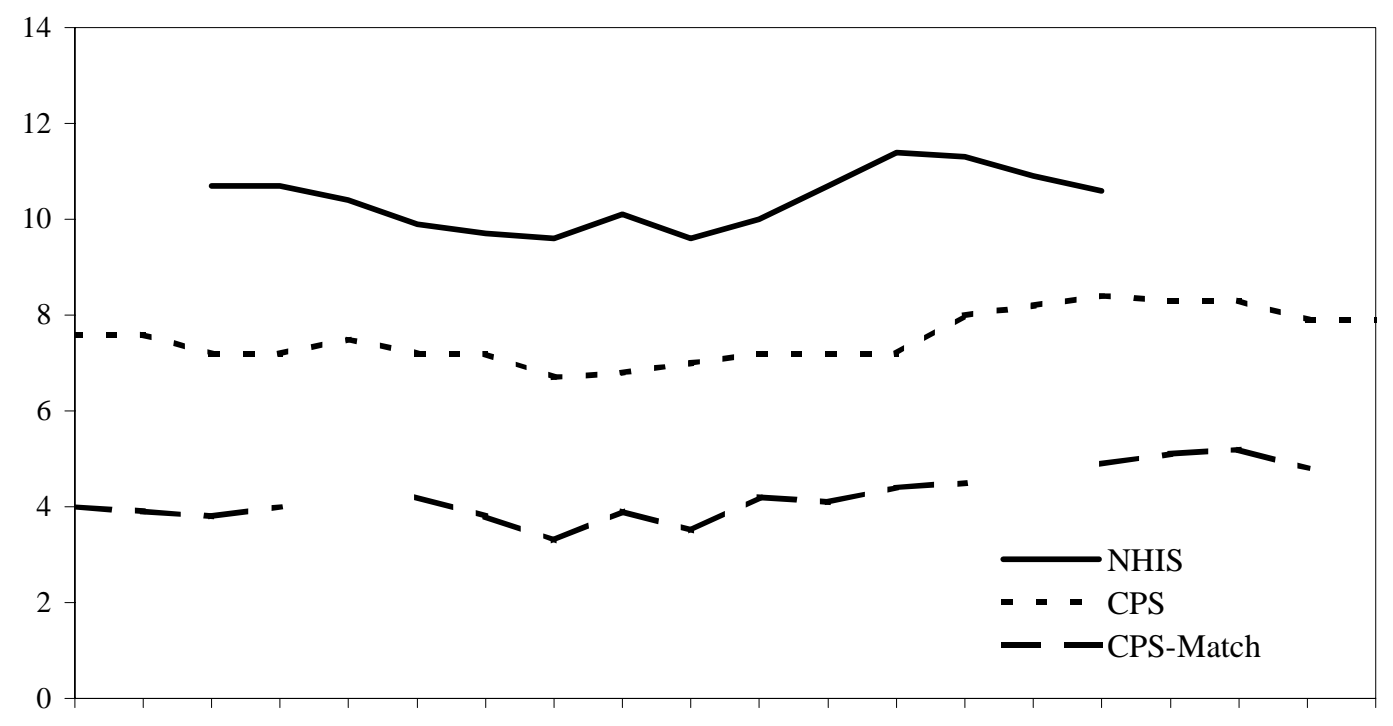

19811982198319841985198619871988198919901991199219931994199519961997199819992000

(First) Survey Year

Source: Authors' calculations using the NHIS, 1983-1996 and the CPS, 1981-2000. 
Figure 5. Employment Trends Among Working Age Persons with Work Limitation-Based Disabilities, by Gender and Data Set.

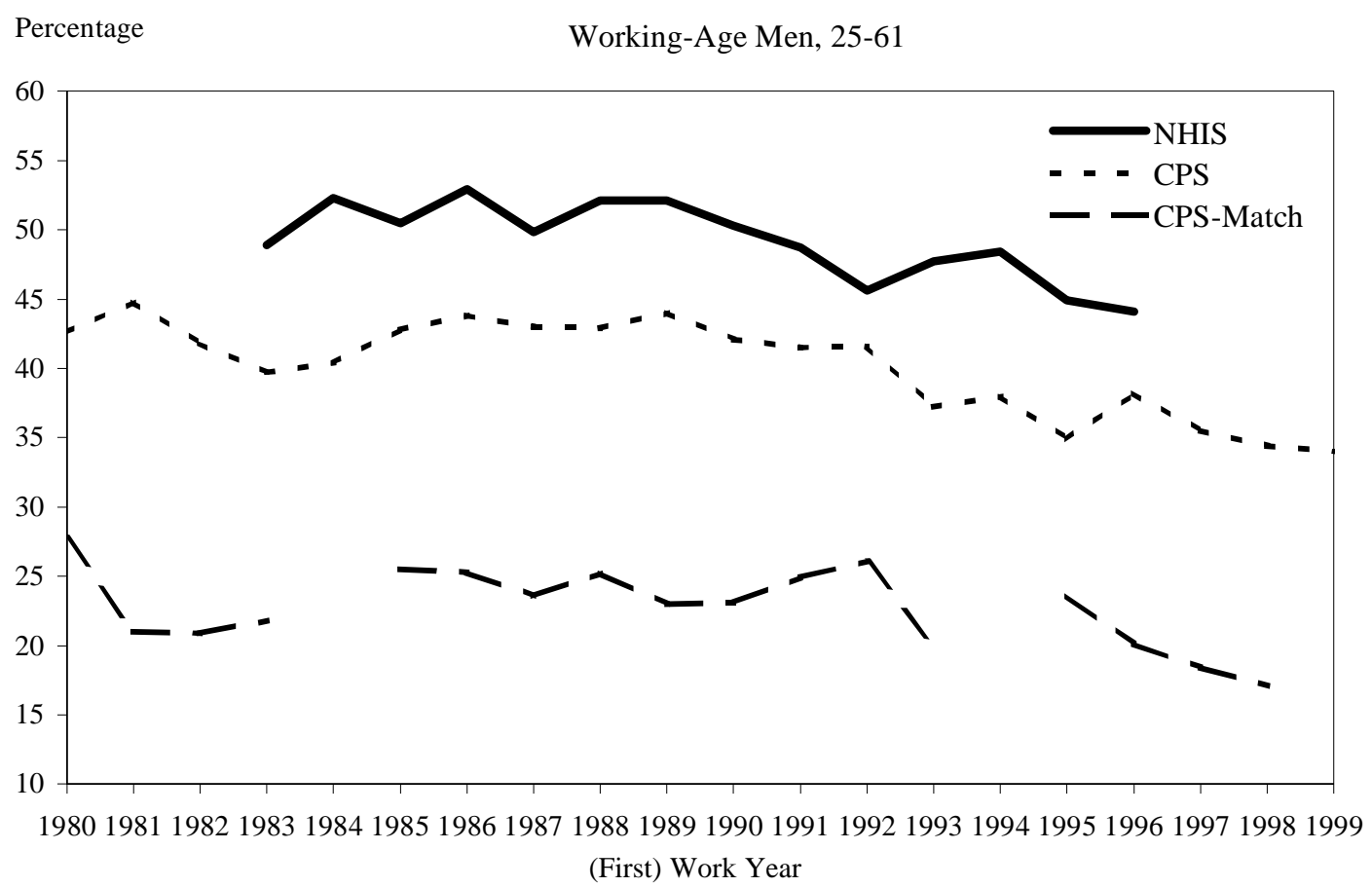

Percentage $\quad$ Working-Age Women, 25-61

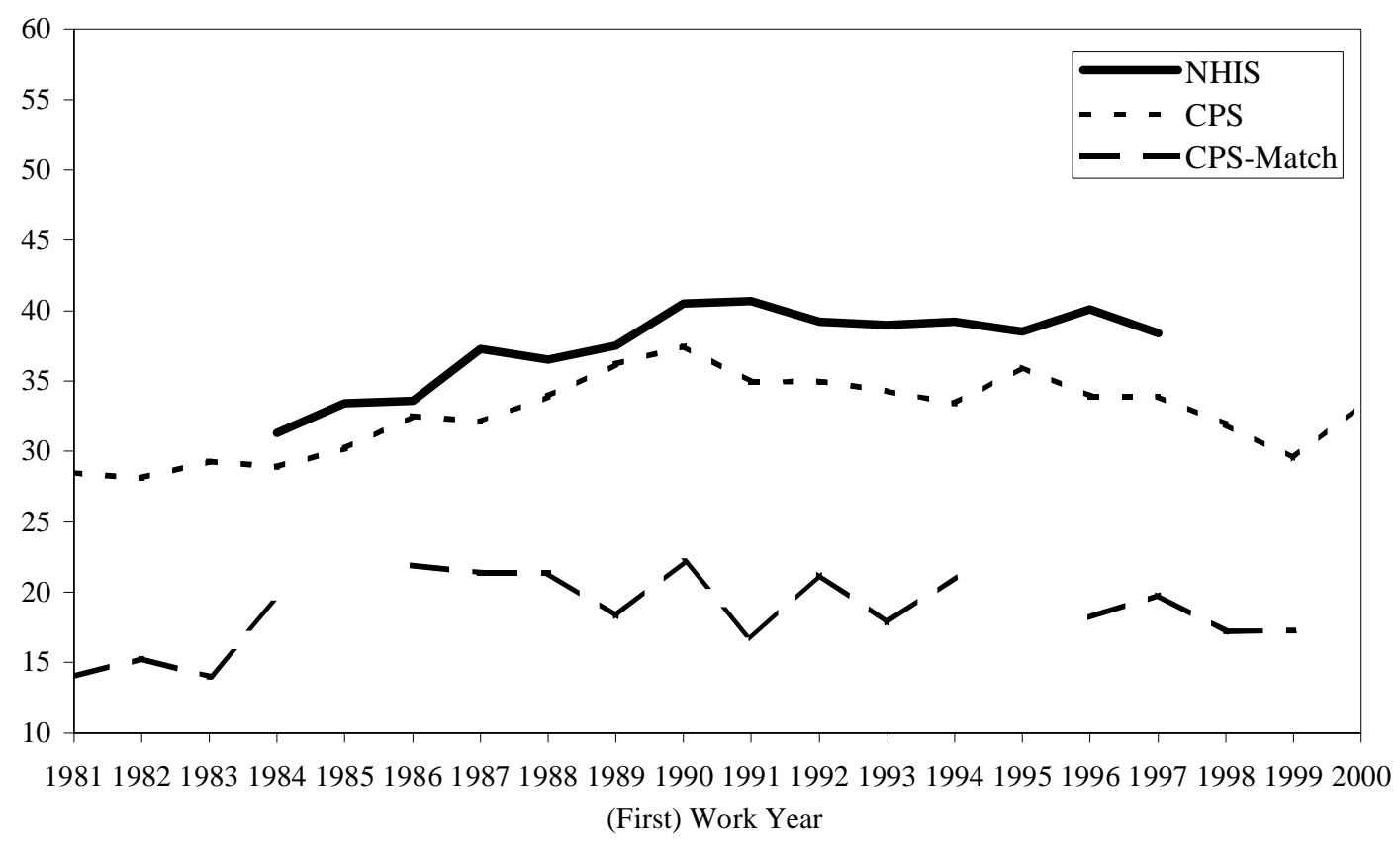

Source: Authors' calculations using the NHIS, 1983-1996, and CPS 1981-2000. 
Table 1. Prevalence of Work Limitation Among Working-Age Men and Women

\begin{tabular}{lccc}
\hline Group & $\begin{array}{c}\text { Impairment } \\
\text { Prevalence } \\
\text { Rate }\end{array}$ & $\begin{array}{c}\text { Percent } \\
\text { Reporting } \\
\text { Work Limitation }\end{array}$ & $\begin{array}{c}\text { Percent } \\
\text { Reporting } \\
\text { No Work Limitation }\end{array}$ \\
\hline Impairments & 19.52 & 25.90 & 74.10 \\
Blind - Both Eyes & 0.15 & 69.03 & 30.97 \\
Other Visual Impairments & 1.83 & 36.24 & 63.76 \\
Deaf - Both Ears & 0.37 & 38.00 & 62.00 \\
Other Hearing Impairments & 7.49 & 23.39 & 76.61 \\
Stammering and Stuttering & 0.42 & 33.35 & 66.65 \\
Other Speech Impairments & 0.26 & 64.90 & 35.10 \\
Paraplegia, Hemiplegia, or Quadriplegia & 0.11 & 90.25 & 9.75 \\
Paraparesis or Hemiparesis & 0.05 & 88.55 & 11.45 \\
Cerebral Palsy & 0.09 & 74.54 & 25.46 \\
Mental Retardation & 0.29 & 90.20 & 9.80 \\
Other Impairments & 11.74 & 27.23 & 72.77 \\
\hline Sourc: Authors' & &
\end{tabular}

Source: Authors' calculations using the NHIS pooled over 1983-1996.

Table 2. Employment Rates of Working-Age Men and Women with Impairments by Work Limitation Status.

\begin{tabular}{lccc}
\hline & \multicolumn{3}{c}{ Employment Rate } \\
\cline { 2 - 4 } Group & Total & Work-Limited & Not Work-Limited \\
\hline Impairments & 72.5 & 41.5 & 83.4 \\
Blind - Both Eyes & 39.1 & 20.3 & 81.1 \\
Other Visual Impairments & 63.0 & 31.6 & 80.9 \\
Deaf - Both Ears & 68.0 & 40.8 & 84.6 \\
Other Hearing Impairments & 73.6 & 39.6 & 83.9 \\
Stammering and Stuttering & 65.4 & 23.7 & 86.3 \\
Other Speech Impairments & 44.0 & 29.1 & 71.6 \\
Paraplegia, Hemiplegia, or Quadriplegia & 25.1 & 20.0 & 72.4 \\
Paraparesis or Hemiparesis & 31.2 & 26.6 & 66.7 \\
Cerebral Palsy & 42.4 & 32.4 & 71.7 \\
Mental Retardation & 30.6 & 28.4 & 51.6 \\
Other Impairments & 72.9 & 45.2 & 83.3 \\
\hline
\end{tabular}

Source: Authors' calculations using the NHIS pooled over 1983-1996. 
Table 3. Employment Rates of Working-Age Men and Women, by Disability Status 1982, 1989, 1992, 1999

\begin{tabular}{ccccc}
\hline & \multicolumn{4}{c}{ Employment Rate } \\
\cline { 2 - 5 } Work Year & \multicolumn{3}{c}{ Wenen } \\
\cline { 2 - 5 } 1980 & Without Disability & With Disability & Without Disability & With Disability \\
1982 & 96.7 & 42.6 & 69.2 & 28.5 \\
1989 & 95.0 & 41.7 & 69.2 & 29.3 \\
1992 & 96.0 & 43.9 & 77.0 & 37.4 \\
1999 & 94.7 & 41.6 & 77.6 & 34.2 \\
& 95.1 & 33.9 & 81.5 & 33.3 \\
$1980-1982$ & & \multicolumn{2}{c}{ Percentage Change } & 2.8 \\
$1982-1989$ & -1.8 & -2.1 & 0.0 & 24.3 \\
$1980-1989$ & 1.0 & 5.1 & 10.7 & 27.0 \\
$1989-1992$ & -0.7 & 3.0 & 10.7 & -8.9 \\
$1992-1999$ & -1.4 & -5.4 & 0.8 & -2.7 \\
$1989-1999$ & 0.4 & -20.4 & 4.9 & -11.6 \\
\hline S0urce: Auth & -0.9 & -25.7 & 5.7 & \\
\hline
\end{tabular}

Source: Authors' calculations based on the March CPS, 1981-2000. 


\begin{tabular}{|c|c|c|}
\hline & Current Population Survey & National Health Interview Survey \\
\hline Background & $\begin{array}{l}\text { The CPS is a monthly survey of the non-institutionalized population of } \\
\text { the United States. Information is collected on labor force } \\
\text { characteristics. In March of each year, the CPS basic monthly survey is } \\
\text { supplemented with the Annual Demographic Survey. This supplement } \\
\text { focuses on sources of income, government program participation, } \\
\text { previous employment, insurance, and a variety of demographic } \\
\text { characteristics. The CPS and the Annual Demographic Survey are used } \\
\text { extensively by government agencies, academic researchers, policy } \\
\text { makers, journalists, and the general public to evaluate government } \\
\text { programs, economic well-being and behavior of individuals, families } \\
\text { and households. }\end{array}$ & $\begin{array}{l}\text { The annual cross-sectional survey of the non-institutionalized civilian } \\
\text { population of the United States. The federal government uses data from } \\
\text { the NHIS to monitor trends in illness and disability. Researchers use } \\
\text { these data to analyze access to health care and health insurance and to } \\
\text { evaluate federal health programs. }\end{array}$ \\
\hline Agency & Census Bureau on behalf of the Bureau of Labor Statistics & Center for Disease Control and Prevention \\
\hline Survey Universe & $\begin{array}{l}\text { Resident population of the United States: citizens living abroad are not } \\
\text { surveyed. Those in long-term care facilities are excluded. }\end{array}$ & $\begin{array}{l}\text { Resident civilian population of the United States: Those on active duty } \\
\text { with the Armed Forces and U.S. citizens living abroad are not surveyed, } \\
\text { however, the dependents of those on active duty with the Armed Forces } \\
\text { who live in the U.S. are included. Those in long-term care facilities are } \\
\text { also excluded. }\end{array}$ \\
\hline $\begin{array}{l}\text { Years Available } \\
\text { and Major } \\
\text { Revisions }\end{array}$ & $\begin{array}{l}\text { The CPS began in the early 1940s, however, the work limitation } \\
\text { variable was not asked until 1981. In 1994, major revisions were made } \\
\text { to the Basic Monthly Survey and the labor force questions. The } \\
\text { changes to the March Supplement were less substantial and reflect the } \\
\text { shift to computer-assisted interviews. }\end{array}$ & $\begin{array}{l}\text { The NHIS began in July } 1957 \text {. We use } 1983-1996 \text { because work } \\
\text { limitations and impairment information was consistently collected. } \\
\text { Major revisions were made to the survey instrument in } 1983 \text { and } 1997 \text {. }\end{array}$ \\
\hline $\begin{array}{l}\text { Number of } \\
\text { Participants }\end{array}$ & Approximately 150,000 individuals annually & Approximately 80,000 individuals annually \\
\hline Work Limitation & $\begin{array}{l}\text { The March Supplement asks "[d]oes anyone in this household have a } \\
\text { health problem or disability which prevents them from working or } \\
\text { which limits the kind or amount of work they can do? [If so,] who is } \\
\text { that? (Anyone else?)" Those who answer yes to this question are } \\
\text { considered to report a work limitation. }\end{array}$ & $\begin{array}{l}\text { The NHIS asks "[d]oes any impairment or health problem NOW keep } \\
\text { [person] from working at a job or business? Is [person] limited in the } \\
\text { kind OR amount of work [person] can do because of any impairment?" } \\
\text { Those who answer yes to either question are considered to report a } \\
\text { work limitation. }\end{array}$ \\
\hline
\end{tabular}

\section{Continued}




\begin{tabular}{|c|c|c|}
\hline & Current Population Survey & National Health Interview Survey \\
\hline Impairment & Not Applicable & $\begin{array}{l}\text { Respondents receive one of six condition lists that ask them if they have } \\
\text { a specific condition (we focus on condition list \#2). This method yields } \\
\text { a random sample because being asked about a condition is not } \\
\text { dependent on one's response to another question. This method captures } \\
\text { those with specific conditions but who may or may not report having no } \\
\text { health or functioning difficulties. Only one-sixth of the sample is } \\
\text { directly asked about a specific condition. The set of impairments used } \\
\text { in this paper are blindness in both eyes, other visual impairments, } \\
\text { deafness in both ears, other hearing impairments, stammering and } \\
\text { stuttering, other speech impairments, mental retardation, absence of } \\
\text { both arms/hands, one arm/hand, fingers, one or both legs, feet/toes, } \\
\text { kidney, breast, muscle of extremity, tips of fingers, and/or toes, } \\
\text { complete paralysis of entire body, one side of body, both legs, other } \\
\text { extremity; cerebral palsy, partial paralysis one side of body, legs, other } \\
\text { extremity, other complete or partial paralysis, curvature or other } \\
\text { deformity of back or spine, orthopedic impairment of the back, spina } \\
\text { bifida, deformity/orthopedic impairment of hand, fingers, shoulder(s), } \\
\text { other upper extremity, flatfeet, clubfoot, or other deformity/orthopedic } \\
\text { impairment, and cleft palate. }\end{array}$ \\
\hline $\begin{array}{l}\text { Employment } \\
\text { Measure }\end{array}$ & $\begin{array}{l}\text { People are employed if they work } 52 \text { hours or more and have } \\
\text { positive earnings in the previous year. }\end{array}$ & $\begin{array}{l}\text { People are employed if they had a job in the previous two weeks, which } \\
\text { includes those on layoff. This definition is based on the following } \\
\text { questions: "[during the previous two weeks], did [person] work at any } \\
\text { time at a job or business not counting work around the house? (Include } \\
\text { unpaid work in the family farm/business.) Even though [person] did } \\
\text { not work during those } 2 \text { weeks, did [person] have a job or business?" ... } \\
\text { "Earlier you said that [person] has a job or business but didn't work last } \\
\text { week or the week before. Was [person] ... on layoff from a job?" }\end{array}$ \\
\hline
\end{tabular}


Appendix Table 2A. Impairment- and Work Limitation-Based Disability Prevalence in the NHIS by Gender

\begin{tabular}{ccccccccc}
\hline & \multicolumn{3}{c}{ Men } & \multicolumn{5}{c}{ Women } \\
\cline { 2 - 8 } Survey & Impairment-Based & Work Limitation-Based & Impairment-Based & Work Limitation-Based \\
\cline { 2 - 8 } Year & Prevalence & Standard & Prevalence & Standard & Prevalence & Standard & Prevalence & Standard \\
\hline 1983 & 21.9 & Error & Rate & Error & Rate & Error & Rate & Error \\
1984 & 21.4 & 0.682 & 10.2 & 0.204 & 16.8 & 0.659 & 10.7 & 0.197 \\
1985 & 23.9 & 0.786 & 10.2 & 0.225 & 17.2 & 0.704 & 10.4 & 0.213 \\
1986 & 22.4 & 0.901 & 10.2 & 0.261 & 16.0 & 0.750 & 9.9 & 0.247 \\
1987 & 21.5 & 0.660 & 9.1 & 0.179 & 16.4 & 0.555 & 9.7 & 0.177 \\
1988 & 22.3 & 0.667 & 9.7 & 0.185 & 16.4 & 0.555 & 9.6 & 0.176 \\
1989 & 20.7 & 0.772 & 9.9 & 0.192 & 16.9 & 0.771 & 10.1 & 0.184 \\
1990 & 22.0 & 0.683 & 9.6 & 0.187 & 17.0 & 0.593 & 9.6 & 0.177 \\
1991 & 22.0 & 0.672 & 9.8 & 0.190 & 18.3 & 0.593 & 10.0 & 0.181 \\
1992 & 24.0 & 0.792 & 10.9 & 0.196 & 18.3 & 0.594 & 10.7 & 0.180 \\
1993 & 22.4 & 0.788 & 11.4 & 0.214 & 18.4 & 0.690 & 11.4 & 0.203 \\
1994 & 22.4 & 0.815 & 10.7 & 0.199 & 18.2 & 0.610 & 11.3 & 0.193 \\
1995 & 21.4 & 0.845 & 10.9 & 0.214 & 17.2 & 0.621 & 10.9 & 0.204 \\
1996 & 20.4 & 0.907 & 10.5 & 0.266 & 17.2 & 0.697 & 10.6 & 0.258 \\
\hline
\end{tabular}

Source: Authors' calculations using the NHIS, 1983-1996. 
Appendix Table 3A. Tests for Differences in Disability Prevalence and Employment Rate Trends across Disability Definitions in the NHIS

by Gender

(Standard errors in parentheses)

\begin{tabular}{|c|c|c|c|c|}
\hline \multirow[b]{3}{*}{ Variable } & \multicolumn{4}{|c|}{ Estimated Parameters } \\
\hline & \multicolumn{2}{|c|}{ Prevalence (Figure 2) } & \multicolumn{2}{|c|}{ Employment (Figure 3) } \\
\hline & Men & Women & Men & Women \\
\hline \multirow[t]{2}{*}{ Intercept } & $19.919 *$ & $16.357 *$ & $79.794 *$ & $54.875 *$ \\
\hline & $(1.81)$ & $(1.00)$ & $(4.56)$ & $(3.31)$ \\
\hline \multirow[t]{2}{*}{ Time } & 2.380 & 0.344 & 0.323 & 1.284 \\
\hline & $(1.56)$ & $(0.87)$ & $(2.55)$ & $(1.87)$ \\
\hline \multirow[t]{2}{*}{ Time2 } & -0.713 & -0.167 & 0.096 & -0.008 \\
\hline & $(0.40)$ & $(0.23)$ & $(0.39)$ & $(0.29)$ \\
\hline \multirow[t]{2}{*}{ Time3 } & 0.078 & 0.027 & -0.010 & -0.003 \\
\hline & $(0.04)$ & $(0.02)$ & $(0.02)$ & $(0.01)$ \\
\hline \multirow[t]{2}{*}{ Time4 } & $-0.003 *$ & -0.001 & -- & -- \\
\hline & $(0.001)$ & $(0.001)$ & -- & -- \\
\hline \multirow[t]{2}{*}{ Work Limitation } & $-8.851 *$ & $-5.925 *$ & $-31.810 *$ & $-26.299 *$ \\
\hline & $(2.05)$ & $(1.15)$ & (4.89) & $(3.57)$ \\
\hline \multirow[t]{2}{*}{ Work Limitation*Time } & -2.537 & 0.212 & 1.609 & 1.337 \\
\hline & $(1.76)$ & $(0.99)$ & $(2.73)$ & $(2.01)$ \\
\hline \multirow[t]{2}{*}{ Work Limitation*Time2 } & 0.596 & -0.132 & -0.378 & -0.182 \\
\hline & $(0.46)$ & $(0.26)$ & $(0.42)$ & $(0.31)$ \\
\hline \multirow[t]{2}{*}{ Work Limitation*Time3 } & -0.056 & 0.013 & 0.019 & 0.007 \\
\hline & $(0.05)$ & $(0.03)$ & $(0.02)$ & $(0.01)$ \\
\hline \multirow[t]{3}{*}{ Work Limitation*Time4 } & 0.002 & -0.0003 & -- & -- \\
\hline & $(0.002)$ & $(0.001)$ & -- & -- \\
\hline & \multicolumn{4}{|c|}{ F-Test on the Interaction Coefficients } \\
\hline F-Statistics & 2.17 & $3.84 *$ & 1.29 & 0.30 \\
\hline p-Statistics & 0.11 & 0.02 & 0.30 & 0.82 \\
\hline
\end{tabular}

Source: Authors' calculations using the NHIS, 1983-1996.

Note: To adjust for the fact that the dependent variables are estimates, all regressions are weighted by the reciprocal of their standard errors. 
Appendix Table 4A. Employment Rates of Working-Age Individuals with Impairment- and Work Limitation-Based Disabilities in the NHIS

\begin{tabular}{|c|c|c|c|c|c|c|c|c|}
\hline \multicolumn{9}{|c|}{ by Gender } \\
\hline \multirow{4}{*}{$\begin{array}{l}\text { Work } \\
\text { Year }\end{array}$} & \multicolumn{4}{|c|}{ Men } & \multicolumn{4}{|c|}{ Women } \\
\hline & \multicolumn{2}{|c|}{ Impairment-Based } & \multicolumn{2}{|c|}{ Work Limitation-Based } & \multicolumn{2}{|c|}{ Impairment-Based } & \multicolumn{2}{|c|}{ Work Limitation-Based } \\
\hline & Employment & Standard & Employment & Standard & Employment & Standard & Employment & Standard \\
\hline & Rate & Error & Rate & Error & Rate & Error & Rate & Error \\
\hline 1983 & 80.8 & 1.348 & 48.9 & 0.214 & 57.0 & 1.959 & 31.3 & 0.326 \\
\hline 1984 & 80.9 & 1.407 & 52.3 & 0.191 & 56.6 & 1.802 & 33.4 & 0.321 \\
\hline 1985 & 81.1 & 1.496 & 50.5 & 0.196 & 58.2 & 2.195 & 33.6 & 0.345 \\
\hline 1986 & 78.2 & 1.543 & 52.9 & 0.238 & 60.9 & 2.619 & 37.3 & 0.402 \\
\hline 1987 & 83.7 & 1.098 & 49.8 & 0.169 & 58.5 & 1.794 & 36.5 & 0.289 \\
\hline 1988 & 84.2 & 1.301 & 52.1 & 0.160 & 62.4 & 1.785 & 37.5 & 0.282 \\
\hline 1989 & 85.5 & 1.599 & 52.1 & 0.163 & 63.7 & 2.076 & 40.5 & 0.290 \\
\hline 1990 & 84.2 & 1.290 & 50.3 & 0.171 & 63.0 & 1.637 & 40.7 & 0.281 \\
\hline 1991 & 81.7 & 1.242 & 48.7 & 0.181 & 66.6 & 1.594 & 39.2 & 0.282 \\
\hline 1992 & 81.5 & 1.194 & 45.6 & 0.179 & 61.2 & 1.689 & 39.0 & 0.273 \\
\hline 1993 & 82.9 & 1.278 & 47.7 & 0.185 & 64.9 & 1.699 & 39.2 & 0.297 \\
\hline 1994 & 80.7 & 1.377 & 48.4 & 0.180 & 62.4 & 1.686 & 38.5 & 0.283 \\
\hline 1995 & 78.5 & 1.368 & 44.9 & 0.186 & 65.1 & 1.807 & 40.1 & 0.298 \\
\hline 1996 & 76.7 & 2.043 & 44.1 & 0.225 & 63.8 & 2.700 & 38.4 & 0.374 \\
\hline
\end{tabular}


Appendix Table 5A. Work Limitation-Based Disability Prevalence in the NHIS, CPS, and Matched CPS

\begin{tabular}{|c|c|c|c|c|c|c|c|c|c|c|c|c|}
\hline \multicolumn{13}{|c|}{ by Gender } \\
\hline \multirow{3}{*}{$\begin{array}{c}\text { (First) } \\
\text { Survey } \\
\text { Year }\end{array}$} & \multicolumn{6}{|c|}{ Men } & \multicolumn{6}{|c|}{ Women } \\
\hline & \multicolumn{2}{|c|}{ NHIS } & \multicolumn{2}{|c|}{ CPS } & \multicolumn{2}{|c|}{ Matched CPS } & \multicolumn{2}{|c|}{ NHIS } & \multicolumn{2}{|c|}{ CPS } & \multicolumn{2}{|c|}{ Matched CPS } \\
\hline & $\begin{array}{c}\text { Prevalence } \\
\text { Rate }\end{array}$ & $\begin{array}{c}\text { Standard } \\
\text { Error }\end{array}$ & $\begin{array}{c}\text { Prevalence } \\
\text { Rate }\end{array}$ & $\begin{array}{c}\text { Standard } \\
\text { Error }\end{array}$ & $\begin{array}{c}\text { Prevalence } \\
\text { Rate }\end{array}$ & $\begin{array}{c}\text { Standard } \\
\text { Error }\end{array}$ & $\begin{array}{c}\text { Prevalence } \\
\text { Rate }\end{array}$ & $\begin{array}{c}\text { Standard } \\
\text { Error }\end{array}$ & $\begin{array}{c}\text { Prevalence } \\
\text { Rate }\end{array}$ & $\begin{array}{c}\text { Standard } \\
\text { Error }\end{array}$ & $\begin{array}{c}\text { Prevalence } \\
\text { Rate }\end{array}$ & $\begin{array}{c}\text { Standard } \\
\text { Error }\end{array}$ \\
\hline 1981 & -- & -- & 8.2 & 0.139 & 5.0 & 0.200 & -- & -- & 7.6 & 0.129 & 4.0 & 0.170 \\
\hline 1982 & -- & -- & 8.2 & 0.147 & 5.2 & 0.202 & -- & -- & 7.6 & 0.136 & 3.9 & 0.167 \\
\hline 1983 & 10.9 & 0.211 & 7.8 & 0.142 & 4.8 & 0.198 & 10.7 & 0.197 & 7.2 & 0.131 & 3.8 & 0.168 \\
\hline 1984 & 10.2 & 0.204 & 8.0 & 0.144 & 4.9 & 0.205 & 10.7 & 0.197 & 7.2 & 0.132 & 4.0 & 0.174 \\
\hline 1985 & 10.2 & 0.225 & 8.2 & 0.146 & -- & -- & 10.4 & 0.213 & 7.5 & 0.133 & -- & -- \\
\hline 1986 & 10.2 & 0.261 & 8.3 & 0.147 & 5.3 & 0.216 & 9.9 & 0.247 & 7.2 & 0.132 & 4.2 & 0.181 \\
\hline 1987 & 9.1 & 0.179 & 8.2 & 0.147 & 4.7 & 0.200 & 9.7 & 0.177 & 7.2 & 0.132 & 3.8 & 0.171 \\
\hline 1988 & 9.7 & 0.185 & 7.7 & 0.142 & 4.6 & 0.205 & 9.6 & 0.176 & 6.7 & 0.128 & 3.3 & 0.168 \\
\hline 1989 & 9.9 & 0.192 & 7.6 & 0.146 & 4.7 & 0.204 & 10.1 & 0.184 & 6.8 & 0.133 & 3.9 & 0.177 \\
\hline 1990 & 9.6 & 0.187 & 7.9 & 0.141 & 5.0 & 0.202 & 9.6 & 0.177 & 7.0 & 0.128 & 3.5 & 0.161 \\
\hline 1991 & 9.8 & 0.190 & 7.7 & 0.140 & 4.5 & 0.194 & 10.0 & 0.181 & 7.2 & 0.130 & 4.2 & 0.178 \\
\hline 1992 & 10.9 & 0.196 & 8.1 & 0.144 & 5.3 & 0.210 & 10.7 & 0.180 & 7.2 & 0.131 & 4.1 & 0.177 \\
\hline 1993 & 11.4 & 0.214 & 8.4 & 0.146 & 5.4 & 0.213 & 11.4 & 0.203 & 7.2 & 0.131 & 4.4 & 0.182 \\
\hline 1994 & 10.7 & 0.199 & 8.8 & 0.152 & 5.3 & 0.220 & 11.3 & 0.193 & 8.0 & 0.139 & 4.5 & 0.192 \\
\hline 1995 & 10.9 & 0.214 & 8.5 & 0.150 & -- & -- & 10.9 & 0.204 & 8.2 & 0.141 & -- & -- \\
\hline 1996 & 10.5 & 0.266 & 8.2 & 0.158 & 5.0 & 0.215 & 10.6 & 0.258 & 8.4 & 0.152 & 4.9 & 0.202 \\
\hline 1997 & -- & -- & 8.3 & 0.157 & 5.5 & 0.224 & -- & -- & 8.3 & 0.151 & 5.1 & 0.204 \\
\hline 1998 & -- & -- & 7.8 & 0.152 & 5.2 & 0.216 & -- & -- & 8.3 & 0.150 & 5.2 & 0.207 \\
\hline 1999 & -- & -- & 8.0 & 0.153 & 5.4 & 0.219 & -- & -- & 7.9 & 0.146 & 4.8 & 0.197 \\
\hline 2000 & -- & -- & 8.0 & 0.152 & -- & -- & -- & -- & 7.9 & 0.146 & -- & -- \\
\hline
\end{tabular}


Appendix Table 6A. Tests for Differences in Work Limitation-Based Disability Prevalence and Employment Rate Trends in the NHIS, CPS, and Matched CPS

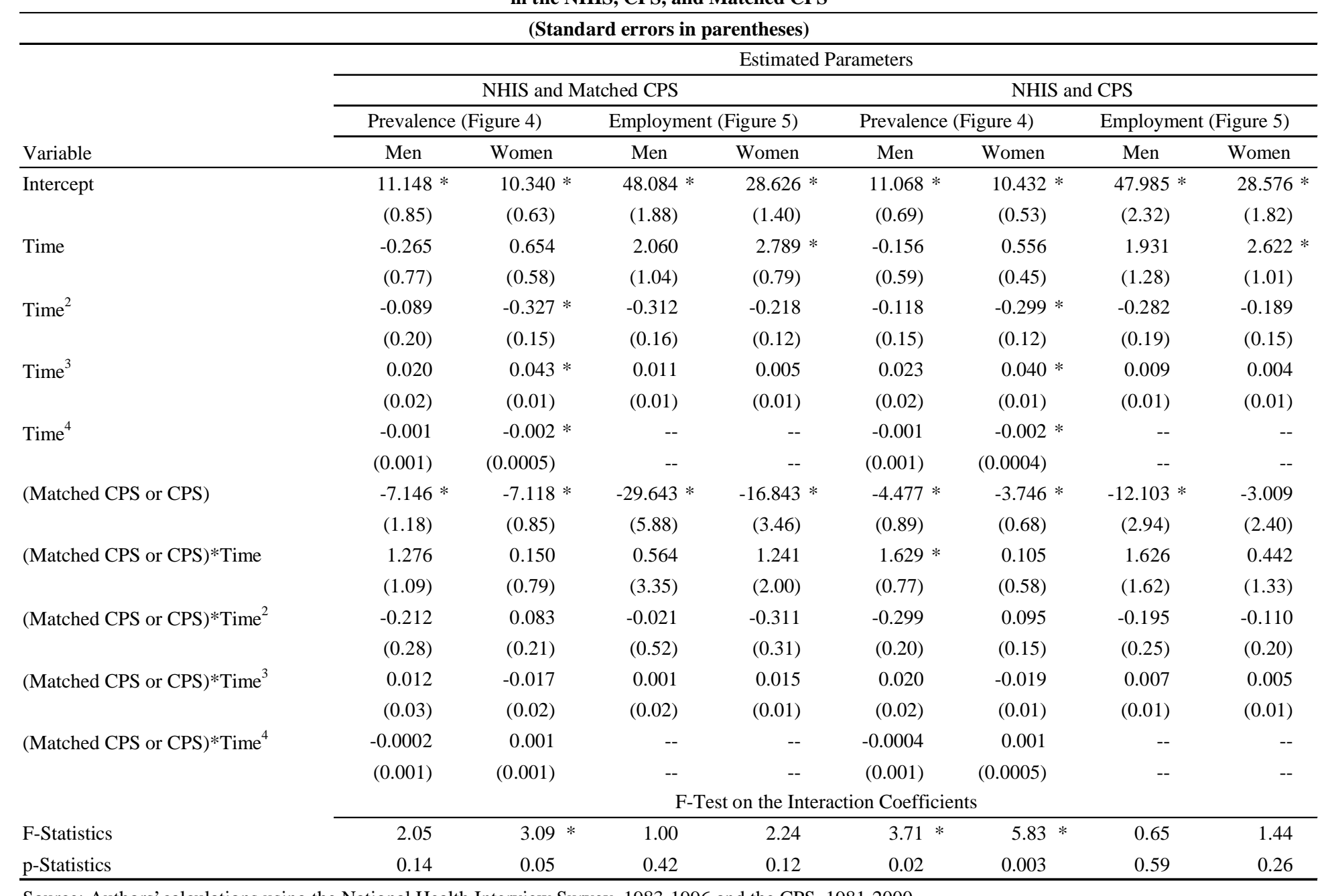

Source: Authors' calculations using the National Health Interview Survey, 1983-1996 and the CPS, 1981-2000.

Note: To adjust for the fact that the dependent variables are estimates, all regressions are weighted by the reciprocal of their standard errors. 
Appendix Table 7A. Employment Rates of Working-Age Individuals with Work Limitation-Based Disabilities in the NHIS, CPS, and Matched CPS

\begin{tabular}{|c|c|c|c|c|c|c|c|c|c|c|c|c|}
\hline \multicolumn{13}{|c|}{ by Gender } \\
\hline \multirow{3}{*}{$\begin{array}{l}\text { (First) } \\
\text { Work } \\
\text { Year }\end{array}$} & \multicolumn{6}{|c|}{ Men } & \multicolumn{6}{|c|}{ Women } \\
\hline & \multicolumn{2}{|c|}{ NHIS } & \multicolumn{2}{|c|}{ CPS } & \multicolumn{2}{|c|}{ Matched CPS } & \multicolumn{2}{|c|}{ NHIS } & \multicolumn{2}{|c|}{ CPS } & \multicolumn{2}{|c|}{ Matched CPS } \\
\hline & $\begin{array}{c}\text { mployment } \\
\text { Rate }\end{array}$ & $\begin{array}{c}\text { Standard } \\
\text { Error }\end{array}$ & $\begin{array}{c}\text { mployment } \\
\text { Rate }\end{array}$ & $\begin{array}{c}\text { Standard } \\
\text { Error }\end{array}$ & $\begin{array}{c}\text { mployment } \\
\text { Rate }\end{array}$ & $\begin{array}{c}\text { Standard } \\
\text { Error }\end{array}$ & $\begin{array}{c}\text { mployment } \\
\text { Rate }\end{array}$ & $\begin{array}{c}\text { Standard } \\
\text { Error }\end{array}$ & $\begin{array}{c}\text { mployment } \\
\text { Rate }\end{array}$ & $\begin{array}{c}\text { Standard } \\
\text { Error }\end{array}$ & $\begin{array}{c}\text { mployment } \\
\text { Rate }\end{array}$ & $\begin{array}{c}\text { Standard } \\
\text { Error }\end{array}$ \\
\hline 1980 & -- & -- & 42.6 & 0.094 & 27.8 & 1.882 & -- & -- & 28.5 & 0.234 & 14.0 & 1.511 \\
\hline 1981 & -- & -- & 44.8 & 0.103 & 21.0 & 1.622 & -- & -- & 28.1 & 0.244 & 15.3 & 1.558 \\
\hline 1982 & -- & -- & 41.8 & 0.120 & 20.9 & 1.736 & -- & -- & 29.3 & 0.244 & 14.0 & 1.555 \\
\hline 1983 & 48.9 & 0.214 & 39.7 & 0.125 & 21.8 & 1.815 & 31.3 & 0.326 & 28.9 & 0.240 & 19.5 & 1.790 \\
\hline 1984 & 52.3 & 0.191 & 40.4 & 0.112 & -- & -- & 33.4 & 0.321 & 30.2 & 0.234 & -- & -- \\
\hline 1985 & 50.5 & 0.196 & 42.8 & 0.112 & 25.5 & 1.887 & 33.6 & 0.345 & 32.5 & 0.235 & 21.9 & 1.916 \\
\hline 1986 & 52.9 & 0.238 & 43.8 & 0.108 & 25.3 & 1.911 & 37.3 & 0.402 & 32.1 & 0.231 & 21.4 & 1.961 \\
\hline 1987 & 49.8 & 0.169 & 43.0 & 0.112 & 23.6 & 1.963 & 36.5 & 0.289 & 33.9 & 0.228 & 21.4 & 2.122 \\
\hline 1988 & 52.1 & 0.160 & 42.9 & 0.115 & 25.2 & 1.968 & 37.5 & 0.282 & 36.2 & 0.231 & 18.3 & 1.788 \\
\hline 1989 & 52.1 & 0.163 & 44.0 & 0.106 & 23.0 & 1.794 & 40.5 & 0.290 & 37.5 & 0.219 & 22.2 & 1.998 \\
\hline 1990 & 50.3 & 0.171 & 42.1 & 0.108 & 23.1 & 1.846 & 40.7 & 0.281 & 34.9 & 0.217 & 16.7 & 1.639 \\
\hline 1991 & 48.7 & 0.181 & 41.5 & 0.115 & 24.9 & 1.798 & 39.2 & 0.282 & 35.0 & 0.218 & 21.3 & 1.848 \\
\hline 1992 & 45.6 & 0.179 & 41.6 & 0.123 & 26.1 & 1.827 & 39.0 & 0.273 & 34.3 & 0.219 & 17.8 & 1.628 \\
\hline 1993 & 47.7 & 0.185 & 37.2 & 0.128 & 20.0 & 1.765 & 39.2 & 0.297 & 33.4 & 0.220 & 21.1 & 1.774 \\
\hline 1994 & 48.4 & 0.180 & 38.0 & 0.124 & -- & -- & 38.5 & 0.283 & 36.0 & 0.218 & -- & -- \\
\hline 1995 & 44.9 & 0.186 & 34.9 & 0.134 & 23.6 & 1.899 & 40.1 & 0.298 & 33.9 & 0.231 & 18.2 & 1.636 \\
\hline 1996 & 44.1 & 0.225 & 38.2 & 0.131 & 20.1 & 1.717 & 38.4 & 0.374 & 33.9 & 0.228 & 19.8 & 1.639 \\
\hline 1997 & -- & -- & 35.5 & 0.126 & 18.4 & 1.696 & -- & -- & 31.9 & 0.225 & 17.2 & 1.541 \\
\hline 1998 & -- & -- & 34.4 & 0.127 & 17.1 & 1.651 & -- & -- & 29.5 & 0.223 & 17.3 & 1.618 \\
\hline 1999 & -- & -- & 34.0 & 0.125 & -- & -- & -- & -- & 33.4 & 0.219 & -- & -- \\
\hline
\end{tabular}

Source: Authors' calculations using the NHIS, 1983-1996 and the CPS, 1981-2000. 
Appendix Table 8A. Tests for Differences in Employment Rate Trends between Working-Age Individuals with and without a Work Limitation-Based Disability

\begin{tabular}{|c|c|c|c|c|}
\hline \multicolumn{5}{|c|}{ by Gender } \\
\hline \multicolumn{5}{|c|}{ (standard errors in parentheses) } \\
\hline & \multicolumn{4}{|c|}{$\begin{array}{ll}\text { Estimated Parameters } \\
\end{array}$} \\
\hline & \multicolumn{2}{|c|}{$1980 \mathrm{~s}$} & \multicolumn{2}{|c|}{$1990 \mathrm{~s}$} \\
\hline Variable & Men & Women & Men & Women \\
\hline \multirow[t]{2}{*}{ Intercept } & $96.90 *$ & $68.30 *$ & $96.20 *$ & $77.00 *$ \\
\hline & $(3.59)$ & $(1.05)$ & $(3.22)$ & $(2.61)$ \\
\hline \multirow[t]{2}{*}{ Time } & -0.54 & 0.59 & -0.49 & 0.32 \\
\hline & $(1.51)$ & $(0.45)$ & $(1.35)$ & $(1.09)$ \\
\hline \multirow[t]{2}{*}{ Time2 } & 0.05 & 0.03 & 0.04 & 0.01 \\
\hline & $(0.13)$ & $(0.04)$ & $(0.12)$ & $(0.10)$ \\
\hline \multirow[t]{2}{*}{ Work Limitation } & $-52.80 *$ & $-40.00 *$ & $-52.20 *$ & $-42.00 *$ \\
\hline & $(3.78)$ & $(1.19)$ & $(3.41)$ & $(2.90)$ \\
\hline \multirow[t]{2}{*}{ Work Limitation*Time } & -0.41 & -0.69 & -0.97 & -0.35 \\
\hline & $(1.59)$ & $(0.50)$ & $(1.43)$ & $(1.21)$ \\
\hline \multirow[t]{3}{*}{ Work Limitation*Time2 } & 0.05 & 0.07 & 0.01 & -0.05 \\
\hline & $(0.14)$ & $(0.04)$ & $(0.13)$ & $(0.11)$ \\
\hline & \multicolumn{4}{|c|}{ F-Test on the Interaction Coefficients } \\
\hline F-Statistics & 0.12 & 1.53 & 3.90 & 5.19 \\
\hline p-Statistics & 0.88 & 0.25 & 0.05 & 0.02 \\
\hline
\end{tabular}

Source: Authors' calculations using the Current Population Survey, 1981-2000.

Note: To adjust for the fact that the dependent variables are estimates, all regressions are weighted by the reciprocal of their standard errors. 
Appendix Table 9A. Employment Rate Counterfactuals in the CPS Allowing for Changes in Age, Race, Education, and Household Size

\begin{tabular}{|c|c|c|c|c|c|c|}
\hline \multirow[b]{4}{*}{ Work Year } & \multicolumn{4}{|c|}{ Men } & & \\
\hline & \multicolumn{2}{|c|}{ Actual } & \multicolumn{2}{|c|}{ Reweighted to 1980} & \multicolumn{2}{|c|}{ Reweighted to 1989} \\
\hline & Without & With & Without & With & Without & With \\
\hline & Work Limitation & Work Limitation & Work Limitation & Work Limitation & Work Limitation & Work Limitation \\
\hline 1980 & 96.7 & 42.6 & 96.7 & 42.6 & -- & -- \\
\hline 1982 & 95.1 & 41.8 & 95.0 & 41.2 & -- & -- \\
\hline 1989 & 96.1 & 44.0 & 95.8 & 42.3 & 96.0 & 43.9 \\
\hline 1992 & 94.8 & 41.6 & 94.5 & 37.4 & 94.8 & 40.0 \\
\hline \multirow[t]{2}{*}{1999} & 95.2 & 34.0 & 94.7 & 30.4 & 95.2 & 33.2 \\
\hline & \multicolumn{6}{|c|}{ Percentage Change } \\
\hline $1980-1982$ & -1.7 & -1.9 & -1.8 & -3.3 & -- & -- \\
\hline 1982-1989 & 1.0 & 5.1 & 0.8 & 2.6 & -- & -- \\
\hline 1980-1989 & -0.6 & 3.2 & -0.9 & -0.7 & -- & -- \\
\hline 1989-1992 & -1.4 & -5.6 & -1.4 & -12.3 & -1.3 & -9.3 \\
\hline 1992-1999 & 0.4 & -20.1 & 0.2 & -20.6 & 0.4 & -18.6 \\
\hline \multirow[t]{2}{*}{ 1989-1999 } & -0.9 & -25.6 & -1.2 & -32.7 & -0.8 & -27.8 \\
\hline & \multicolumn{6}{|c|}{ Women } \\
\hline 1980 & 69.3 & 28.5 & 69.3 & 28.5 & -- & -- \\
\hline 1982 & 69.3 & 29.3 & 68.6 & 28.4 & -- & -- \\
\hline 1989 & 77.0 & 37.5 & 74.4 & 34.0 & 77.0 & 37.4 \\
\hline 1992 & 77.6 & 34.3 & 74.1 & 29.2 & 76.6 & 32.6 \\
\hline \multirow[t]{2}{*}{1999} & 81.6 & 33.4 & 78.1 & 27.0 & 80.2 & 30.4 \\
\hline & \multicolumn{6}{|c|}{ Percentage Change } \\
\hline 1980-1982 & 0.0 & 2.8 & -1.0 & -0.4 & -- & -- \\
\hline 1982-1989 & 10.5 & 24.6 & 8.1 & 17.9 & -- & -- \\
\hline 1980-1989 & 10.5 & 27.3 & 7.1 & 17.6 & -- & -- \\
\hline 1989-1992 & 0.8 & -8.9 & -0.4 & -15.2 & -0.5 & -13.7 \\
\hline 1992-1999 & 5.0 & -2.7 & 5.3 & -7.8 & 4.6 & -7.0 \\
\hline 1989-1999 & 5.8 & -11.6 & 4.9 & -23.0 & 4.1 & -20.6 \\
\hline
\end{tabular}

Source: Authors' calculations using the Current Population Survey, 1981-2000. 